\title{
BIRD BONE REMAINS FROM TWO MEDIEVAL SETTLEMENTS IN DEBRECEN (EASTERN HUNGARY)
}

\author{
ERIKA GÁL* - LÁSZLÓ DARÓCZI-SZABÓ** - MÁRTA DARÓCZI-SZABÓ** \\ *Institute of Archaeology, Research Centre for the Humanities \\ 4 Tóth Kálmán Str., H-1097 Budapest, Hungary \\ gal.erika@btk.mta.hu \\ ** Budapest History Museum \\ 2 Szent György Square, H-1014 Budapest, Hungary \\ darocziszabo.laszlo@btm.hu,darocziszabo.marta@btm.hu
}

\begin{abstract}
This paper presents results on three medieval avian bone assemblages found at Debrecen-Monostor-erdő and Debrecen-Tócó-part, respectively. Domestic chicken yielded most of the bird remains to evidence the exploitation of adult birds for egg production and flock maintenance in particular. In addition, feather harvesting and fat production could have been the target of goose (and possibly duck) husbandry. Although the goose bone sizes resemble the greylag goose, the keeping of an unimproved form of domestic goose rather than the hunting of the wild ancestor is suggested by the structure of the assemblage and the presence of healed bones. Wild birds seem to have been rarely consumed by the settlers of the two villages, but the feathers or wings or carcasses of diurnal birds of prey and crows may have been used for special purposes. Either killed for their symbolic meaning or only persecuted for protecting the backyard animals, the red kite (Milvus milvus) and the hen harrier (Circus cyaneus) represent new species for the medieval avifauna of Hungary, similarly to the Northern shoveler (Anas clypeata) and the Northern lapwing (Vanellus vanellus) that could have been hunted in the marshy environment provided by the Tócó creek. Moreover, the use of trained saker falcon (Falco cherrug) for hawking cannot be excluded either. In addition to the exploitation of birds for the abovementioned goods and values, two needle cases made from goose bones evidence the utilization of their skeletal parts as raw material for producing artefacts as well.

Keywords: bird bones, Middle Ages, Debrecen-Monostor-erdő, Debrecen-Tócó-part, Hungary
\end{abstract}

\section{INTRODUCTION}

The sites of Debrecen-Monostor-erdő and Debrecen-Tócó-part are located in the Northern outskirt of Debrecen (Fig. 1). They have been recently excavated due to the construction of the bypass section of Route 4 in 2008-2010. A rather large area (over 59,000 $\mathrm{m}^{2}$ and $41,000 \mathrm{~m}^{2}$, respectively) were unearthed at both sites under the direction of archaeologists Barbara Kolozsi, Zsigmond Hajdú, Gyöngyvér Emese Nagy and László Szabó, respectively. Consequently, numerous archaeological features from prehistorical and historical ages were opened. Nevertheless, the $10^{\text {th }}-13^{\text {th }}$ century (formally Árpád Period in Hungary) yielded most of the features at Debrecen-Monostor-erdô. Similarly, the early medieval $\left(10^{\text {th }}-13^{\text {th }}\right.$ century $)$ and the late medieval $\left(14^{\text {th }}-15^{\text {th }}\right.$ century $)$ period were the best represented at Debrecen-Tócó-part as well. ${ }^{1}$

Owing to the archaeozoological analyses, thousands of animal bones have been identified from both sites that offer information regarding the people-animal relationship in medieval villages. As a first step, results regarding the avian material are to be presented for understanding the role of domestic and wild birds in the life of peasants and reconstructing the natural environment and seasonal activity around the two settlements under study.

KoLOZSI 2012b.

${ }^{1}$ HaJdú-NAGY 2009; HaJdÚ-NAGY 2010; Kolozsi 2011a; 


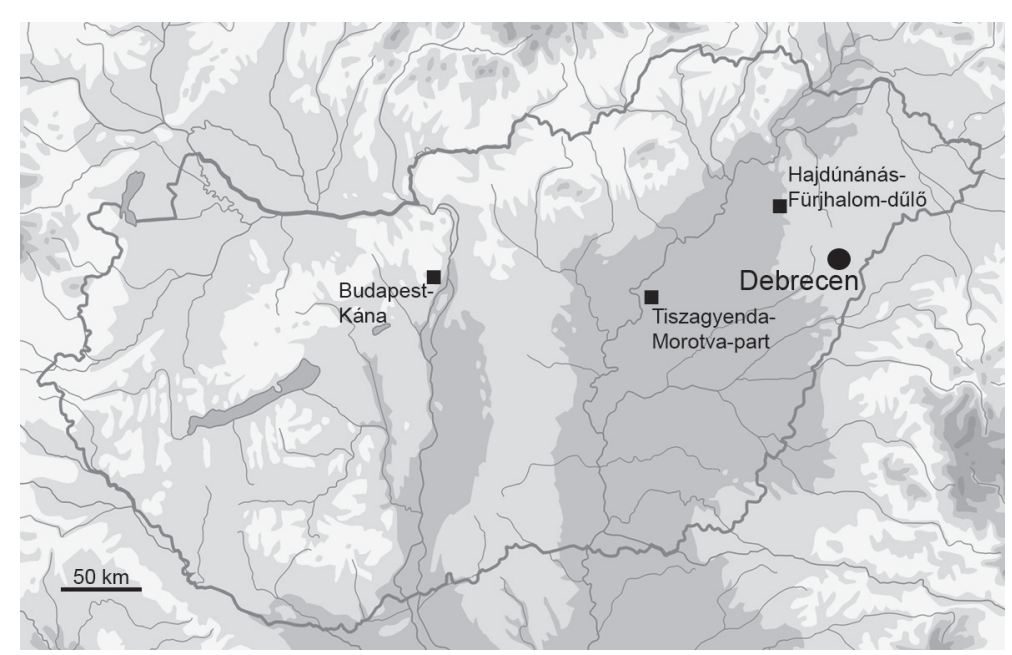

Fig. 1. The location of main sites mentioned in the paper

RESULTS

\section{Debrecen-Monostor-erdö}

At the site of Debrecen-Monostor-erdő, the medieval period was represented by $10^{\text {th }}-13^{\text {th }}$ century and $13^{\text {th }}-14^{\text {th }}$ century finds, respectively. Most of the bird bones $(\mathrm{NISP}=141$ ) assigned to a number of species were found in $10^{\text {th }}-13^{\text {th }}$ features. Contrary, only 14 avian remains from a single species (the domestic chicken) represented the younger period. Owing to the small chronological difference and taxonomic homogeneity, the two assemblages are discussed together as $10^{\text {th }}-14^{\text {th }}$ century avian remains in this paper (Table 1).

Table 1. List of species (NISP = number of identified specimens; $\mathrm{MNI}=$ minimal number of individuals)

\begin{tabular}{|c|c|c|c|c|c|c|}
\hline \multirow[t]{3}{*}{ Species } & \multicolumn{2}{|c|}{ Debrecen-Monostor-erdő } & \multicolumn{4}{|c|}{ Debrecen-Tócó-part } \\
\hline & \multicolumn{2}{|c|}{$10^{\text {th }}-14^{\text {th }} \mathrm{c}$} & \multicolumn{2}{|c|}{$10^{\text {th }}-14^{\text {th }} \mathrm{c}$. } & \multicolumn{2}{|c|}{$\begin{array}{c}\text { Medieval and Late Medieval/ } \\
\text { Modern Period }\end{array}$} \\
\hline & NISP & MNI & NISP & MNI & NISP & $\mathrm{MNI}$ \\
\hline Greylag goose/Domestic goose (Anser anser/A. domesticus) & 52 & 5 & 32 & 2 & 18 & 2 \\
\hline Mallard/Domestic duck (Anas platyrhynchos/A. domestica) & 4 & 1 & & & 7 & 1 \\
\hline Northern shoveler (Anas clypeata) & 1 & 1 & & & & \\
\hline Red kite (Milvus milvus) & 13 & 1 & & & & \\
\hline Buzzard (Buteo buteo) & & & & & 3 & 1 \\
\hline Imperial eagle (Aquila heliaca) & 1 & 1 & & & & \\
\hline Hen harrier (Circus cyaneus) & 2 & 1 & & & & \\
\hline Saker falcon (Falco cherrug) & 1 & 1 & & & & \\
\hline Partridge (Perdix perdix) & & & & & 1 & 1 \\
\hline Domestic chicken (Gallus domesticus) & 75 & 7 & 32 & 5 & 110 & 10 \\
\hline Northern lapwing (Vanellus vanellus) & & & 1 & 1 & & \\
\hline Rook/Hooded crow (Corvus frugilegus/C. corone) & 6 & 2 & & & 1 & 1 \\
\hline Total identified & 155 & 20 & 65 & 8 & 140 & 16 \\
\hline Unidentifiable bird (Aves sp. indet.) & 30 & & & & 36 & \\
\hline Total bird & 185 & & 65 & & 176 & \\
\hline
\end{tabular}


Bird bones formed $3.6 \%$ of the total animal bone assemblage (NISP $=5,065 ;$ Fig. 2). They were found in a total of 27 features representing houses, pits, pit holes, and wells. A number of features enclosed articulated bones of birds representing complete or incomplete skeletons. In spite of the small bird bone assemblage, a number of species could be identified including domestic and wild species as well.

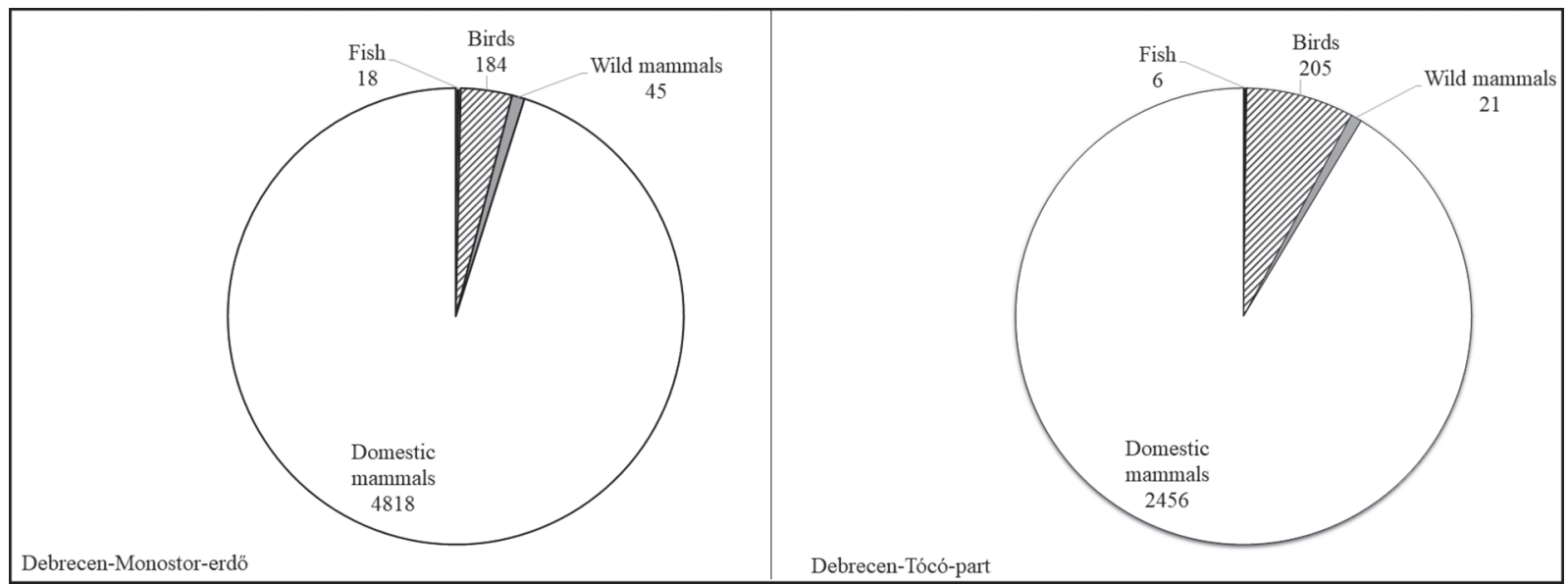

Fig. 2. The distribution of animal bones by the main taxonomic groups

Domestic chicken (Gallus domesticus Linnaeus, 1758)

This species was the most frequent in the assemblage by 75 remains originating from at least seven individuals. Features 101 (pit), 271 (well), 337 (pit), and 412 (pit) contained the bones of female birds. Features 268 (well) and 307 (house) enclosed the remains of male birds (cocks). The sexing of females was based either on the presence of medullary bone tissue (Features 101 and 271) or the lack of cockspur on the tarsometatarsus (Features 337 and 412). Contrary, the presence of cockspur pointed to males.

Medullary bone tissue in the femora of the female bird from Feature 101 evidences its killing during the egglaying period. ${ }^{2}$ Regarding the male bird found in Feature 307, it has to be noted that its left tarsometatarsus was bent and it displayed aging outgrowing below the cockspur. It is also noteworthy that only the remains of adult birds were identified when the estimation of age of remains was possible (i.e. at least one of the epiphyses of bones were present).

Greylag goose/Domestic goose (Anser anser/A. domesticus)

The next most frequent bird was goose yielding 52 remains that could be assigned to at least five individuals. Majority of them represented articulated bones and they were found in Features 97 (well), 120 (well), 143 (well), and 183 (pit). Separating the bones of domestic goose from its wild ancestor, the greylag goose is rarely possible because of morphological similarities and size overlapping. Moreover, the occurrence of feral domestic geese, as well as the hybrids of wild and domestic forms, is also possible since greylag goose is an autochthonous species in our region (Fig. 3).

However, since the goose bone assemblage included two complete tarsometatarsi, the ratio of these bones were illustrated on a plot diagram in order to show their dimensions in comparison to a number of recent greylag and domestic geese. The result indicated that the sizes of goose bones from Debrecen-Monostor-erdő fell closer to the dimensions of wild ancestor than of the domestic form. Nevertheless, two specimens among the domestic geese displayed rather small dimensions evidencing the great size variety that may occur in modern poultry keeping (Fig. 4).

It also has to be considered that domestic goose in the Middle Ages must have been smaller than most of the recent breeds whose skeletons are to be found in the recent comparative collections. Therefore, similar number of remains and skeletal distribution to domestic chicken would suggest the breeding of domestic goose at the settlement, although sporadic hunting of the wild form cannot be excluded either.

\footnotetext{
${ }^{2}$ SerJeAntson 2009, 47-53.
} 
From this point of view, the pathological conditions identified on two bones of the specimen found in Feature 120 are especially interesting. Marks of healing of fracture-dislocation were identified on the proximal part of the left ulna diaphysis. In addition, the distal epiphysis of left tibiotarsus displayed slight exostosis. There is no doubt that a severe fracture of the wing bone hinders a migratory bird in flying. Therefore, if the remains from Debrecen-Monostor-erdő belonged to a greylag goose that suffered an accident, this bird must have been rescued and cared by people as the healed breakage points to. Human mistreatment, however, may also cause injuries in birds kept in captivity. Exostosis may form on a bone due to a number of reasons including infections and the advanced age of bird connected to increased body weight. ${ }^{3}$

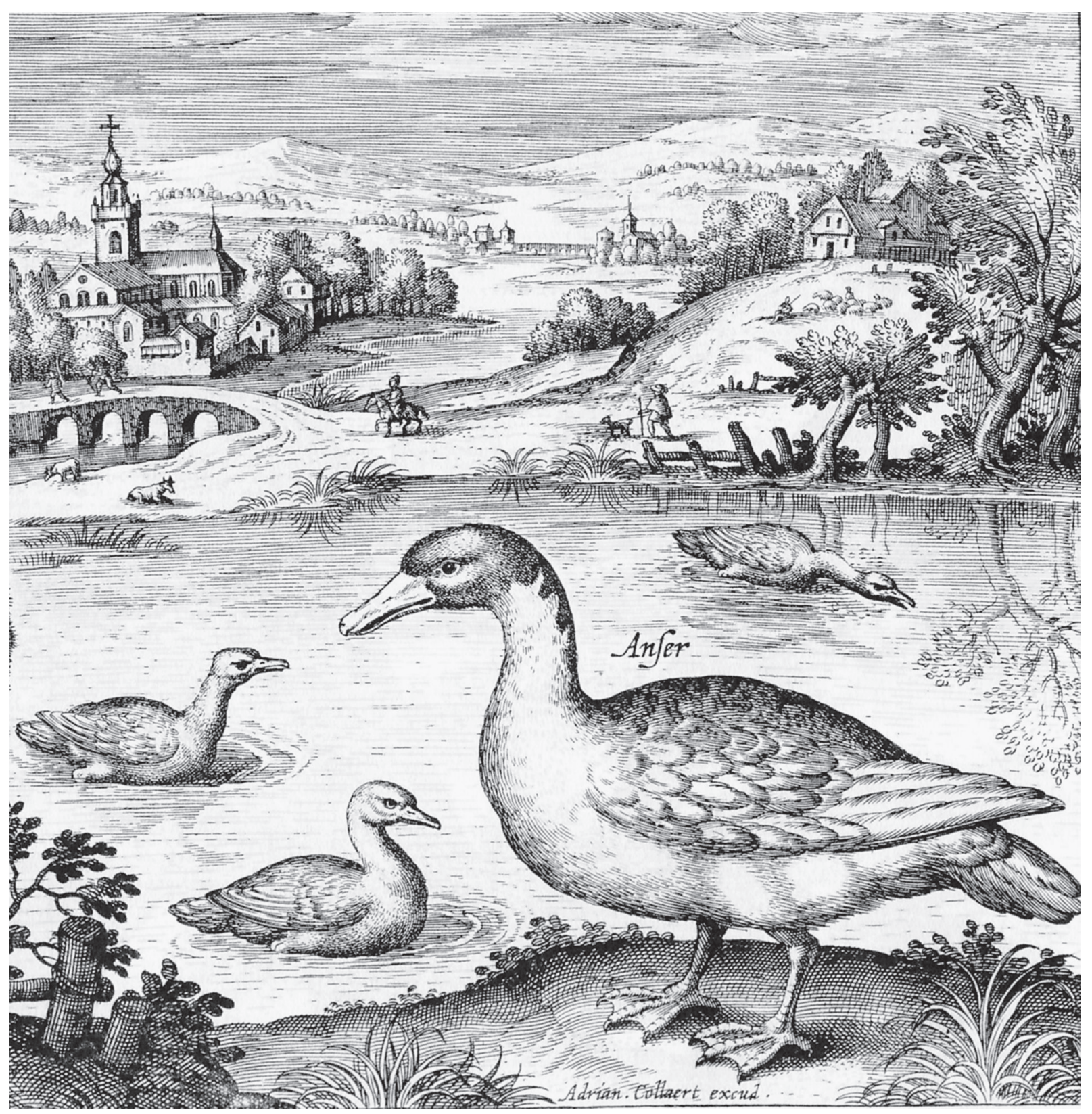

Fig. 3. Illustration of goose from Adrian Collaert's album (first published around 1660) ${ }^{4}$

${ }^{3}$ BARTOSIEWICZ-GÁL 2003，226-227, Figs 196-197;

${ }^{4}$ Collaert 1967.

BARON 2018, 221

Acta Archaeologica Academiae Scientiarum Hungaricae 71, 2020 


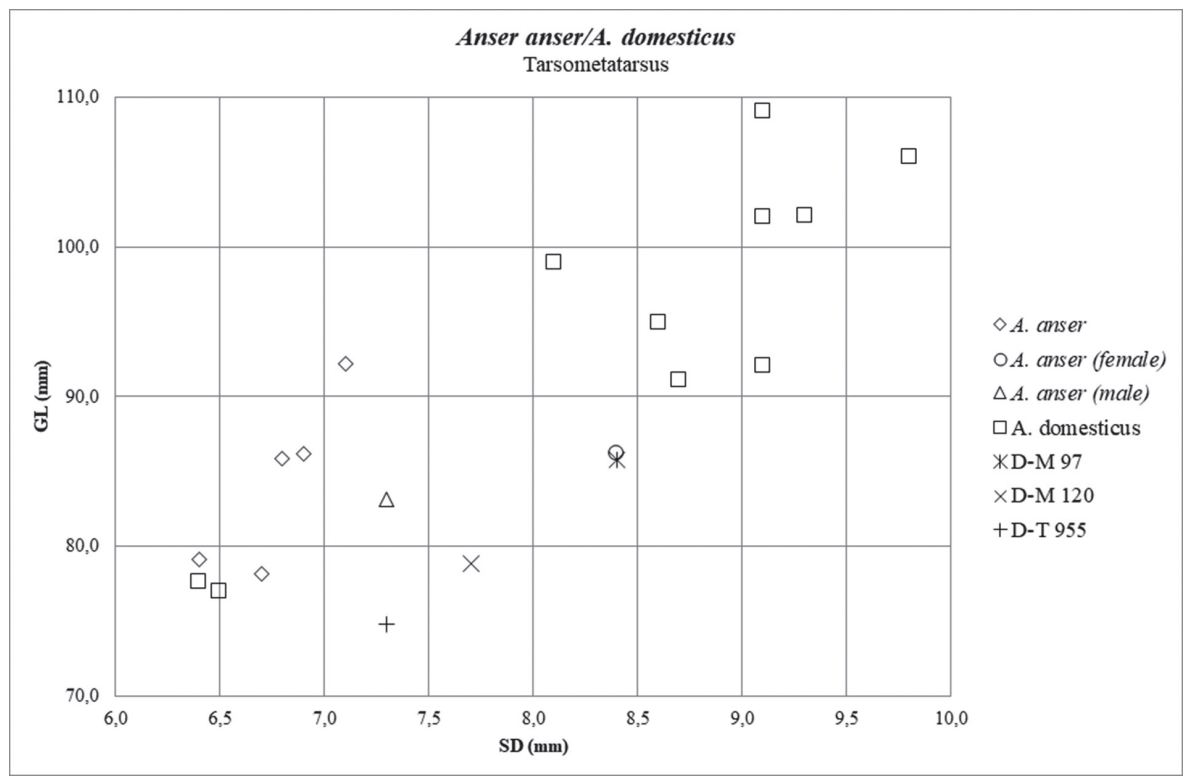

Fig. 4. Size variation in goose tarsometatarsus. Abbreviations: $\mathrm{GL}=$ greatest length; $\mathrm{SD}=$ smallest diameter

\section{Mallard/Domestic duck (Anas platyrhynchos/A. domestica)}

The separation of domestic duck from its wild ancestor, the mallard presents the same difficulties as described above concerning the goose. Only four remains assigned to a single specimen were found in Feature 212 (house).

Northern shoveler (Anas clypeata Linnaeus, 1758)

In addition to mallard or domestic duck, a smaller size duck species could be identified by a single remain. The complete humerus from the Northern shoveler was also found in a house (Feature 361).

Red kite (Milvus milvus Boddaert, 1783)

The almost complete skeleton of this species of diurnal bird of prey was unearthed from a pit (Feature 465). Some of the bones such as the ulna, the radius, the carpometacarpus, and the tibiotarsus contained medullary bone tissue. Contrary, the humerus and tarsometatarsus did not contain medullary bone tissue (Fig. 5).

Imperial eagle (Aquila heliaca Savigny, 1809)

This large predatory bird yielded the proximal fragment of a humerus (Fig. 6) that was found in a house (Feature 188).

Hen harrier (Circus cyaneus Linnaeus, 1766)

The two remains originating from this species were also found in a house (Feature 361). The incomplete synsacrum and the left fragment of ilium represented articulated bones from the pelvic girdle of a single individual.

Saker falcon (Falco cherrug Gray, 1834)

This species was identified from an almost complete ulna. It was found in the same house (Feature 188) from where the imperial eagle bone came.

Rook/Hooded crow (Corvus frugilegus/C. corone)

Rook and/or hooded crow yielded six remains from two individuals. The skeletal parts including the skull as well as the wing and leg bones of an adult crow also came from the house (Feature 188) that contained the remains of two diurnal birds of prey. In addition, an ulna and a femur of a subadult individual were found in a pit (Feature 213). 


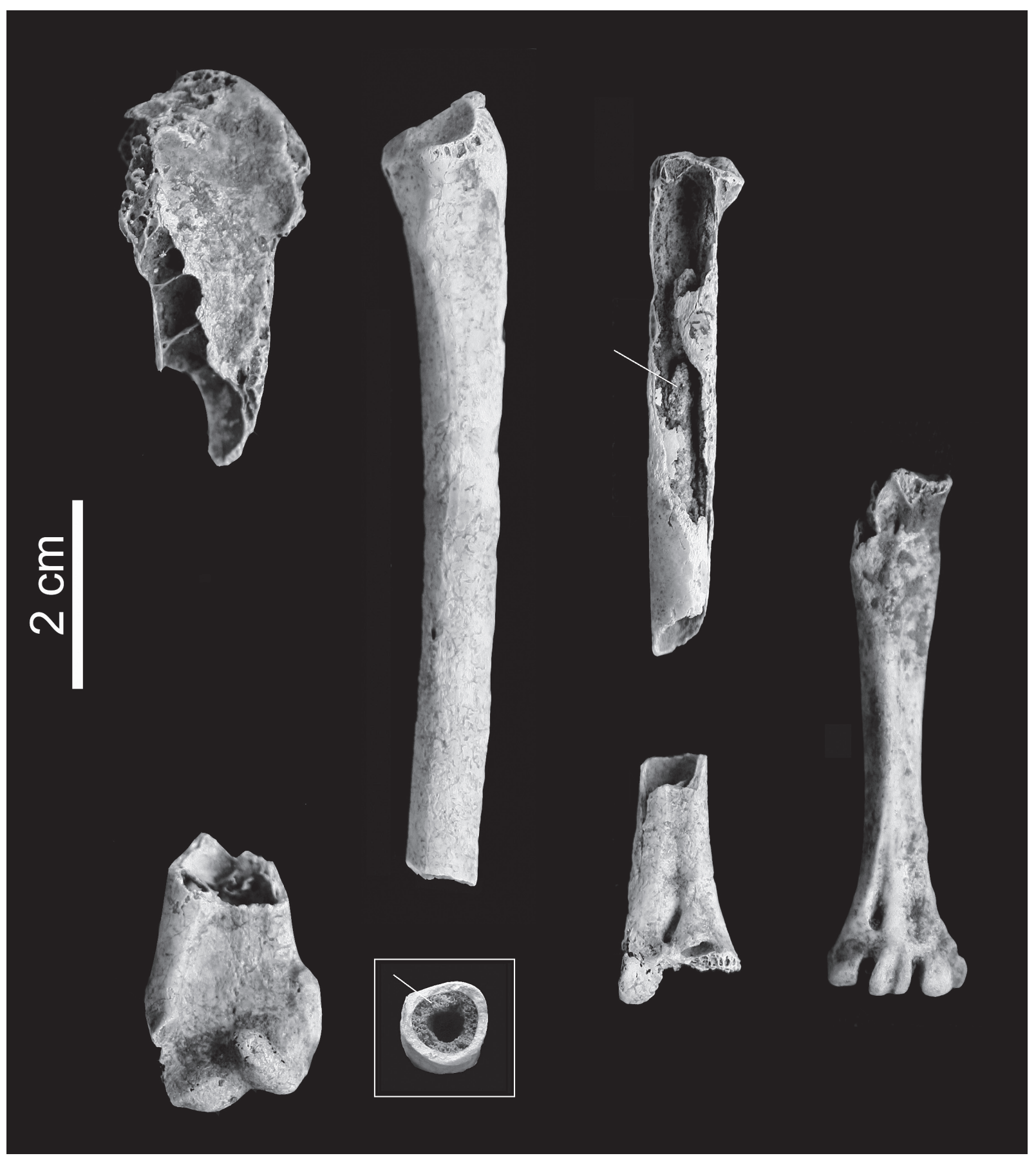

Fig. 5. Fragments of the humerus, ulna, tibiotarsus, and the complete tarsometatarsus of the red kite. The enlargement in the white square shows the cross-section picture of the ulna diaphysis. The arrows indicate the medullary bone tissue in bones 


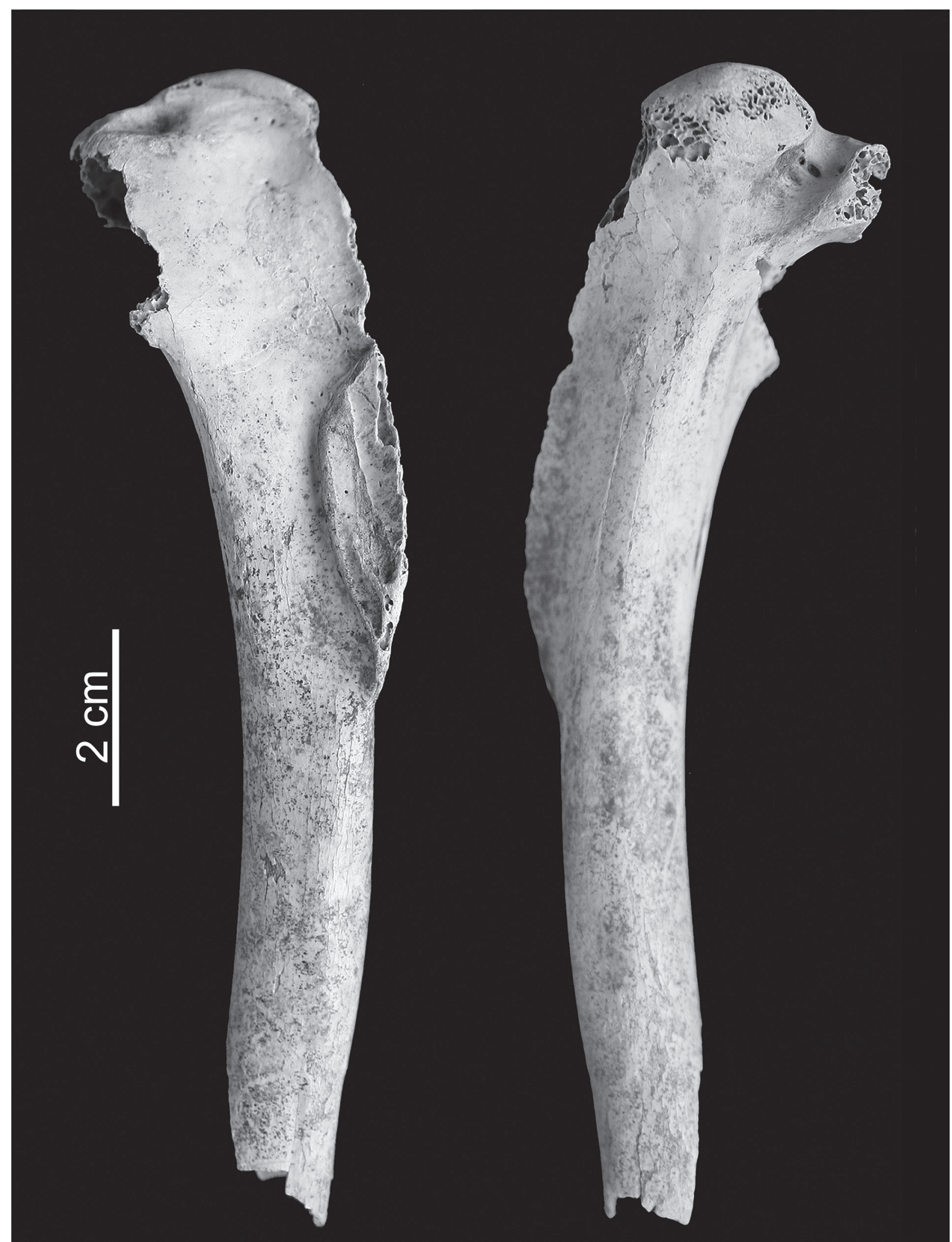

Fig. 6. Proximal fragment of the left humerus from the imperial eagle. Left: cranial view, right: caudal view 
An attempt for the separation of the two closely related species was made by using the morphological and metrical criteria published by Teresa Tomek and Zbigniew M. Bochenski. Owing to the fragmented and in some cases not fully ossified bones, the application of both methods failed. Moreover, the sizes of the humerus from Feature 188 fit the hooded crow, while the measurements of the femur from the probably same individual better suited the sizes of the rook than the hooded crow (Table 2). ${ }^{5}$

Taphonomic features and bone manufacture

A number of domestic chicken and goose remains showed hack- and cut marks. One of the most interesting among them is the skull of goose found in Feature 120 that had been transversally cut at the middle suggesting the extraction of the brain. The left humerus from this skeleton displayed marks of bone working as well. The distal part of diaphysis had been cut around, but the manufacturing process was not finished.

In addition, certain avian remains also showed marks of gnawing. Since they did not have a special character, it is difficult to assign them to any carnivorous or omnivorous species. Adult dogs usually are able to entirely consume the fragile bird bones. Puppies and cats, however, tend to only chew the avian remains because of their undeveloped and small teeth. Pigs may also leave gnawing marks on animal bones.

\section{Debrecen-Tócó-part}

This site yielded animal bones from various periods of the Middle Ages. Similarly to the site of DebrecenMonostor-erdö, the earliest stage was represented by $10^{\text {th }}-13^{\text {th }}$ and $13^{\text {th }}-14^{\text {th }}$ century remains. Since only seven domestic chicken bones represented the younger era, the two assemblages will be discussed together as the $10^{\text {th }}-14^{\text {th }}$ century bone material in the followings. Even so, it represents a small assemblage including 65 identified avian bones from only three species.

The larger bird bone assemblage, found in medieval and late medieval - early Modern Period features, comprises 140 remains. This material could be assigned to six bird species (Table 1).

The avian remains from Debrecen-Tócó-part represented 7.6\% of the total animal bone assemblage (NISP = 2,688; Fig. 2). They were found in 40 features representing pits, pit holes, wells, and ovens. Just like at Debrecen-Monostor-erdő, a number of features enclosed articulated bones of birds representing complete or incomplete skeletons.

Domestic chicken

This species yielded the remains of two juveniles, a subadult, and two adult individuals in the $10^{\text {th }}-14^{\text {th }}$ century assemblage. The adult individuals were represented by a few skeletal elements which did not provide any information regarding the sex of birds. An almost complete skeleton of a juvenile domestic chicken was found in Feature 856 (pit).

Contrary, the younger assemblage mostly included the remains of adult specimens whose sex could be identified according to the afore presented criteria. Of seven individuals, three represented females, while four were males. Three almost complete skeletons of female birds were found in Features 327 (well), 436 (well), and 462 (pit). The complete skeleton of a cock came from Feature 313 (pit). In addition to the seven adult individuals, scattered remains of three juveniles were also found in this assemblage.

Greylag goose/Domestic goose

The $10^{\text {th }}-14^{\text {th }}$ century bone material contained as many geese as domestic chicken remains. The almost complete skeleton of a goose found in Feature 310 (well) formed the majority of the 32 goose bone assemblage (Table 2). Among the three disarticulated goose bones, two displayed traces of working.

The medieval and late medieval - early Modern Period assemblage included only 18 goose remains. Most of them represented the skeleton of an adult specimen coming from Feature 462 (pit).

${ }^{5}$ TOMEK-BOCHENSKI 2000.

Acta Archaeologica Academiae Scientiarum Hungaricae 71, 2020 
Mallard/Domestic duck

Duck remains were found only in the medieval assemblage. The partial skeleton of an adult individual was found in Feature 726 (pit).

Buzzard (Buteo buteo Linnaeus, 1758)

Three distal wing bones (ulna, radius and carpometacarpus) represented this diurnal bird of prey. All the three complete bones were found in Feature 462 (pit) dated to the late medieval - early Modern Period era.

Partridge (Perdix perdix Linnaeus, 1758)

The single remain, a complete humerus also came from a medieval pit (Feature 467).

Northern lapwing (Vanellus vanellus Linnaeus, 1758)

Similarly to the aforementioned species, the Northern lapwing yielded a complete humerus. It was unearthed from Feature 358 (pit) dated to the $10^{\text {th }}-14^{\text {th }}$ century.

Rook/Hooded crow

The only crow remains. a complete tarsometatarsus was found in a late medieval pit (Feature 952).

Taphonomic features and bone manufacture

Only a few bird remains found in the $10^{\text {th }}-14^{\text {th }}$ century assemblage displayed marks that could be associated with food preparation and consumption. They included cut marks on a domestic chicken femur and a goose humerus, as well as a fire mark on a domestic chicken tibiotarsus.

Nevertheless, two avian bones displayed traces of manufacturing. A possible needle case made from the diaphysis of goose ulna was found in Feature 390 that was an oven (Fig. 7). Another half-made or broken needle box made from the diaphysis of goose humerus came from Feature 475 that was a pit (Fig. 8). Two similar artefacts were identified from the coeval village of Kána located in the suburbs of modern-day Budapest. One of them (found in Feature 1647 that was a pit) is a finished artefact and was found in full length. The other, coming from Feature 3516 (pit) also seems to have been finished, but only its fragment was found. ${ }^{6}$

A rather small number of remains bearing cut and gnawing and fire marks could be identified in the medieval and late medieval - early Modern Period assemblage as well. In addition to poultry species, the partridge humerus displayed cut mark. Traces of fire mostly occurred on the bones of the domestic chicken skeleton found in a well (Feature 327).

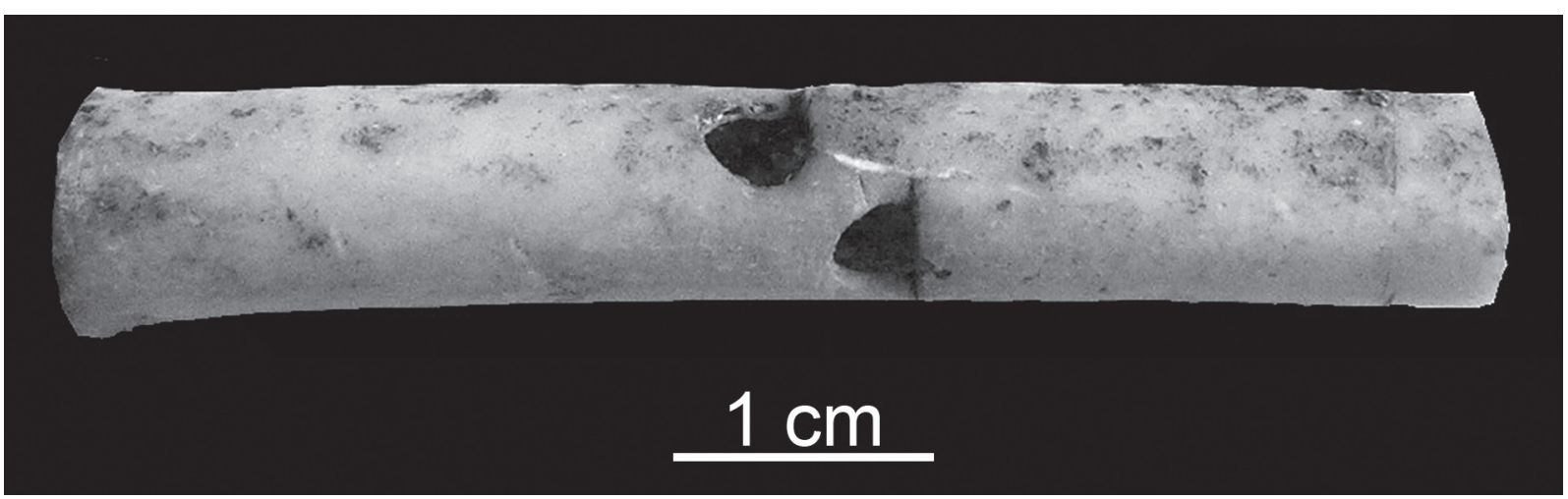

Fig. 7. Needle case found in Feature 390 at Debrecen-Tócó-part

${ }^{6}$ DARÓCZI-SZABÓ 2013, 88-89. 


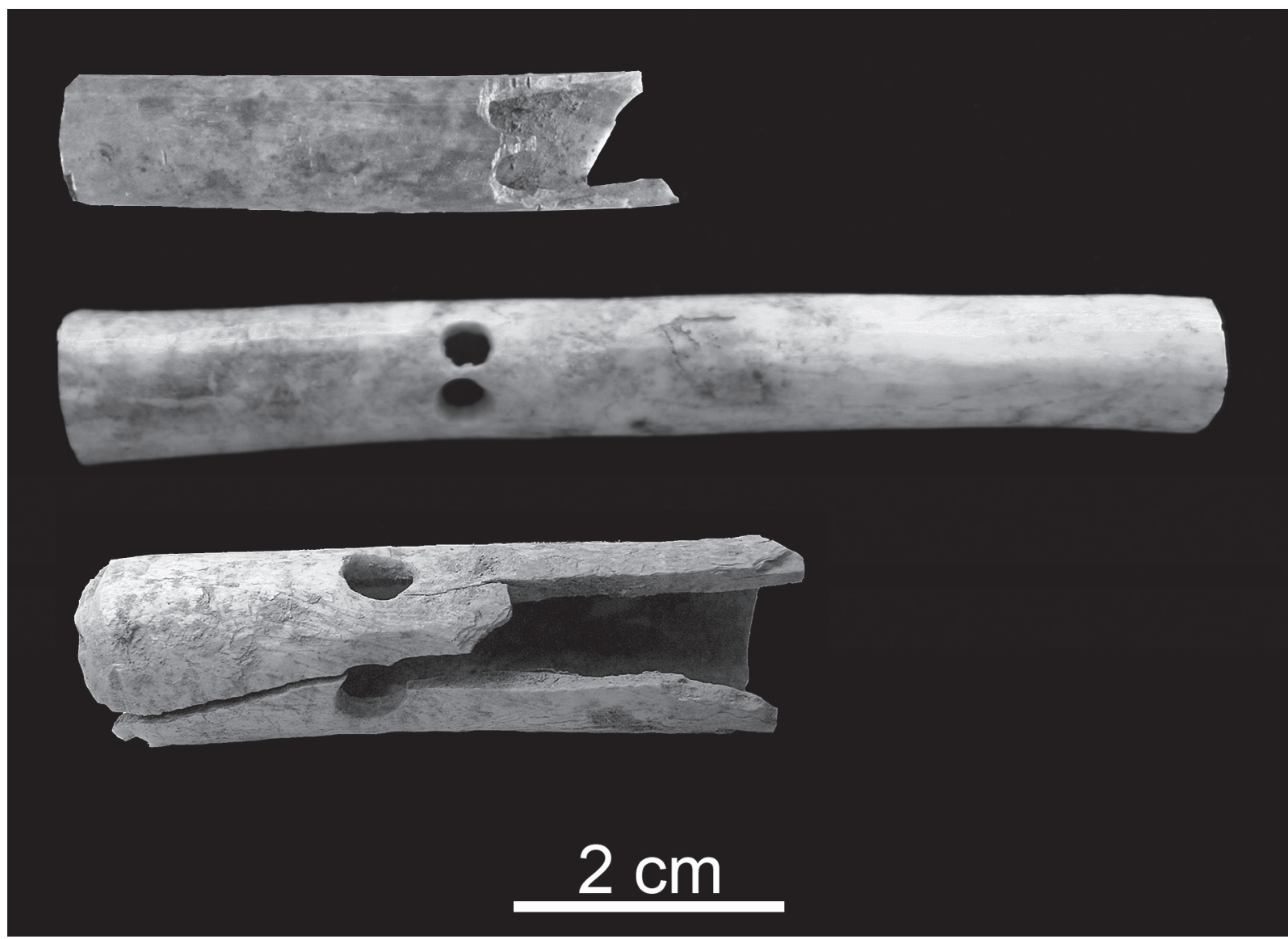

Fig. 8. Semi-finished needle case from Debrecen-Tócó-part (top) in comparison to a similar type of finished (middle) and broken (bottom) object found at the coeval site of Budapest-Kána

\section{DISCUSSION}

Animal husbandry and hunting during the Middle Ages and the Ottoman Period is rather well documented in Hungary. In addition to summary papers discussing archaeozoological assemblages from the present-day territory of the country both according to chronological periods and settlement types, ${ }^{7}$ a recent revision also includes data from sites located in the adjacent areas of Hungary that used to belong to the medieval Kingdom of Hungary. ${ }^{8}$ Studies focusing particularly on avian remains representing either poultry species and hunted birds exploited for their meat, feathers, and other values, or raw material for producing bone artefacts have been recently published as well. ${ }^{9}$

Nevertheless, bird bones were generally underrepresented in most of the rural assemblages, ${ }^{10}$ such as at the early medieval $\left(10^{\text {th }}-13^{\text {th }}\right.$ century) site of Hajdúnánás-Fürjhalom-dülő nearby Debrecen, where the avian remains $(\mathrm{NISP}=14)$ made up only $1.4 \%$ of the total animal bones. ${ }^{11}$ The recently studied rather abundant bone material unearthed at the coeval site of Kána (NISP $=12,025)$ contained only $347(3.7 \%)$ bird bones. ${ }^{12}$ Similarly low representation of fowls was noted in the late medieval $\left(14^{\text {th }}-16^{\text {th }}\right.$ century) assemblage from Tiszagyenda-Morotva-part in Eastern Hungary, where only 112 bird remains $(2.3 \%)$ were found in the total bone assemblage $(\mathrm{NISP}=4,823) .{ }^{13}$ Thus the contribution of birds (3.6\%) to the assemblage unearthed at Debrecen-Monostor-erdo fits into the trend.

al. 2018 .

${ }^{7}$ BARTOSIEWICZ-GÁL 2003; VÖRÖS 2003; BARTOSIEWCZ et

${ }^{8}$ GÁL manuscript $a$.

${ }^{9}$ GÁL 2005; GÁL 2008; GÁL 2015.
${ }^{10}$ GÁL manuscript a, Appendix 4.

${ }^{11}$ GÁl 2010.

${ }^{12}$ Daróczi-Szabó 2013, 12-13, Fig. 3.

${ }^{13}$ LyUbLyanOVICS 2018, 147, Table 3.5.8 A. 
Avian remains were somewhat better represented at Debrecen-Tócó-part by $7.6 \%$ of bones. The most likely reason for this seems to be the higher number of articulated skeletons than in the assemblage from Debrecen-Monostor-erdő.

The distribution of remains according to the main taxonomic groups indicated that meat supply was based on animal husbandry at both settlements (Fig. 2). Contrary to the overrepresentation of remains from domestic mammals, poultry seems to have been rarely killed according to the small number of remains and individuals assigned to fowls (Table 1). This hypothesis is based on the scarcity of bones from juvenile and subadult birds in addition to the general underrepresentation of avian remains in the assemblage.

Domestic chicken seems to have been exploited for eggs rather than for meat as evidenced by the overrepresentation of female birds and the presence of skeletal parts containing medullary bone tissue in the assemblage. Egg-consumption was also proved by the amount of eggshell remains found in nine features including pits, well and oven at Debrecen-Tócó-part. On the other hand, the number of cocks identified from both sites indicates the keeping of both female and male birds for maintaining the poultry flock. Goose and duck, if these species represent the domestic forms, could have been exploited for their feathers and fat as well. ${ }^{14}$ According to the great number of complete or almost complete skeletons from domestic chicken, goose and duck found in a number of features, the carcasses of slaughtered birds do not seem to have been shared but consumed by a few people, most possibly families. The rarely occurring gnawing marks on the bones also suggest that the food remains were quickly buried. Carefulness in this respect may have been important in the hot season in order to avoid the bad smells and animals feeding on butchery and kitchen remains.

Owing to the number of sexed tarsometatarsi from domestic chicken, the size distribution of this species could be illustrated. The plot diagram showing the ratios of the greatest length (GL) to the smallest diameter (SD) of the tarsometatarsus evidence the separation of sexes (cocks being larger than hens) on the one hand, and the slight size increase through time on the other (Fig. 9).

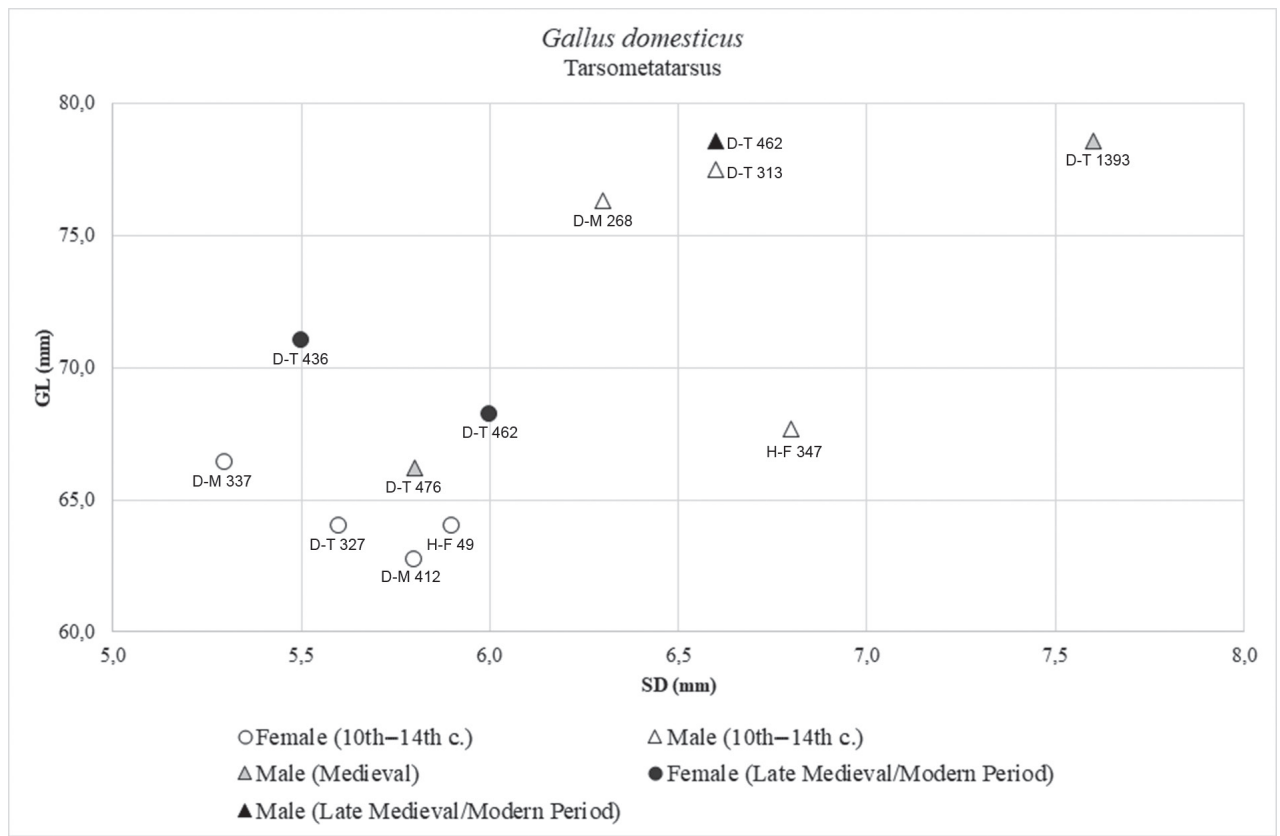

Fig. 9. Size variation in domestic chicken tarsometatarsus. Abbreviations: D-M=Debrecen-Monostor-erdő; D-T= Debrecen-Tócó-part; $\mathrm{H}-\mathrm{F}=$ Hajdúnánás-Fürjhalom-dülő. The numbers indicate the number of features

In addition, notable is the rather great size difference among the cocks identified from the early medieval sites in the region of Debrecen. As far as the dimensions of hens from Debrecen-Monostor-erdő, Debrecen-Tócópart and Hajdúnánás-Fürjhalom-dülő form a group, the size of cock from the latter settlement falls much behind the measurements of cocks from Debrecen. Striking size differences among medieval domestic chicken have been al-

${ }^{14}$ DARÓCZI-SZABÓ 2012. 
ready documented, however, but so far only from high-status settlements. The presence of small and large type individuals could be proved at the late medieval ecclesiastical site of Esztergom-Castle hill-Quarry and the Ottoman Period palisade fort at Barcs, respectively. ${ }^{15}$ One of the reasons for the scarcity of fish and bird remains in the assemblages under study may be that the excavation methods did not include wet sieving and dry screening, but the bones were gathered by hand collecting only. Nevertheless, the bigger remains of wild mammals were also underrepresented in both assemblages that would evidence the opportunistic character of hunting in both villages (Fig. 2).

Indeed, the partridge, the Northern shoveler and the Northern lapwing each yielded a single remain only. As long as the partridge used to be the most frequently hunted bird in the Middle Ages, the last two species have been first identified from a medieval assemblage in Hungary. ${ }^{16}$

The Northern shoveler and the Northern lapwing live in the marshy environment and occur in Hungary during the breeding and migration season - from (early) spring to (late) autumn - only. The partridge is a year-round bird of open grassy fields and agricultural lands. ${ }^{17}$ These species may have been randomly killed during fishing and hunting for common game animals such as hare, roe deer and wild boar.

The most interesting wildfowls are the number of diurnal birds of prey. Four different species - the red kite, the imperial eagle, the hen harrier and the saker falcon - were identified from Debrecen-Monostor-erdő. Such a richness of predatory birds has not been published before from any type of medieval site including even highstatus settlements. ${ }^{18}$ Recently, however, also four species of diurnal birds of prey have been described from the rural site of Kána in a doctoral thesis. ${ }^{19}$ Nevertheless, only the saker falcon is common in the two lists.

Interestingly, both the imperial eagle and the saker falcon were represented by wing bones and they were found in Feature 188 that was a house. This would have hinted to a special place where bird wings or feathers may have been used for any purpose, especially that the partial skeleton of crow was also unearthed from this house. Nevertheless, Feature 188 contained several hundreds of animal bones, indicating that it was filled with refuse material after it had been abandoned.

The imperial eagle is a rarely occurring species in archaeological assemblages. So far it was only identified from the $16^{\text {th }}-18^{\text {th }}$ century Pilisszentkereszt Monastery in Hungary. ${ }^{20}$ Although its use in falconry at the latter site cannot be excluded, the imperial eagle does not seem to have a significance in hawking according to the specialist literature. ${ }^{21}$ Neither is this fowl listed among the birds of prey used for hunting in medieval England, although the wildly used popular work 'Book of St Albans' dated to 1486 discusses a large variety of birds according to the social ranks of owners. ${ }^{22}$

Living in open grasslands and meadows, the imperial eagle mostly hunts for small mammals and less frequently for birds. In Hungary, its main prey is the ground squirrel (Spermophilus citellus F. Cuvier, 1825). ${ }^{23}$ Thus it could have been killed either around the site or at the settlement when protecting the farmed animals.

Last, but not least, it is worth mentioning that eagles were consumed during the Middle Ages. The cookbook of Anna Bornemisza (the wife of Michael Apafi, elected Prince of Transylvania) from 1680 includes nine recipes regarding the preparation of this large bird of prey. ${ }^{24}$ Although this book was the Hungarian version of the royal source 'Ein neu Kochbuch' written by the Chef of the Mainz Elector Marx Rumpolt in 1581, and thus it mostly concerned the late medieval elite society, the fragment of tibiotarsus from a golden eagle (Aquila chrysaetos Linnaeus, 1758) bearing hack mark on its distal end in the food refuse at the site of Kána suggests that predatory birds may have been consumed by anyone in the medieval times. ${ }^{25}$ The find from Debrecen-Monostor-erdö is a fragment of humerus, while the latter type of bone is holding the biggest amount of meat (muscle) in the bird wing.

Contrary to the imperial eagle, the saker falcon is among the most appreciated species used in hunting with birds for both fur game and fowl. It was associated with knights in the aforementioned Book of St Albans. ${ }^{26}$ Being a species adapted to open grasslands whose distribution area extends from the Carpathian Basin throughout the continental steppe zone to Mongolia, its use in falconry in our region is thought to be as early as the Hungarian Conquest. $^{27}$
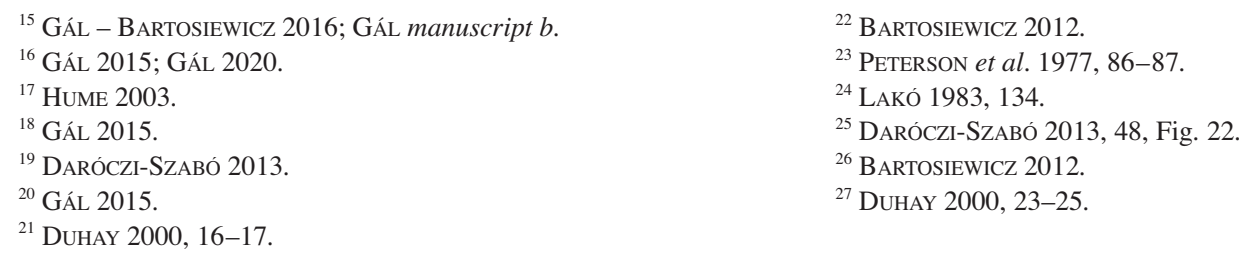

Acta Archaeologica Academiae Scientiarum Hungaricae 71, 2020 
The saker falcon yielded an incomplete ulna at Debrecen-Monostor-erdő. In the assemblage from Kána, seven bones assigned to a male saker were found. Although common predatory birds used in falconry such as the Northern goshawk (Accipiter gentilis Linnaeus, 1758) and the Eurasian sparrow hawk (A. nisus Linnaeus, 1758) as well as their most frequent prey were also identified from Kána, equipment and accessories used in falconry proving the engagement of trained birds were not found at that settlement. ${ }^{28}$ Regarding the possible role of the saker at Debrecen-Monostor-erdö, the complete analysis of archaeological material shall bring the subject forward.

As for the red kite, its archaeozoological evidence from medieval Hungary is first described. Since the medullary bone tissue reaches full density in the bones of females right before laying the eggs, this specimen must have killed either at the beginning or at the end of the egg-laying period when the medullary bone tissue is forming in the bones or, contrary, absorbing. Nowadays the red kite rarely breeds in Hungary. It hunts over open fields with scattered trees and makes its large nest on trees, and usually hatches $2-4$ eggs between March-June. ${ }^{29}$

This species is not valued in falconry at all having thus excluded the interest of people in the capture and foster of red kite chicks. Moreover, the carcass of this individual found at Debrecen-Monostor-erdő does not seem to have been disarticulated and used for any reason but entirely discarded into a pit. It may have belonged to a hungry female bird that flew too close to the settlement for a living prey or carrion, and thus it was killed. Modern evidence for displaying a carcass of a bird of prey as the enemy of settlers is also known in rural environments. ${ }^{30}$

Hen harrier has been also first identified from a medieval assemblage in Hungary. Similarly to the previous three birds of prey, this species also hunts over meadows, grasslands and agricultural lands. Nevertheless, the hen harrier is a winter visitor in Hungary occurring from October to April thus evidencing seasonal activity of the settlers during the cold period of the year as well. ${ }^{31}$

Buzzard is the only diurnal bird of prey identified from Debrecen-Tócó-part. Three articulated bones forming the distal part of the right wing were found in the late medieval - early Modern Period assemblage. Although buzzard is a common diurnal bird of prey occurring year-round in Hungary, it has been an infrequent record in archaeozoological assemblages. This is the second bone evidence for this species at a rural site in addition to the $13^{\text {th }}$ century village of Muhi. ${ }^{32}$

Though buzzard is easy to be trained, it is not really used in falconry since it shows interest only towards its natural prey. ${ }^{33}$ Nevertheless, similarly to the red kite, buzzard also eats carrion. ${ }^{34}$ Therefore it is likely that this species was killed by people and its wing was used for every day (e.g. feather duster) or symbolic reason.

Finally, in addition to the various sides of people-bird interaction and exploitation of this group of vertebrates, the use of avian bones as raw material is also worth discussing. Needle boxes made from bones represented common tools in medieval households ${ }^{35}$ Since the gracile tubular bones with thin wall and round cross-section were the best raw material for producing this type of utensil, they were usually made either from bird bones or sheep and goat tibiae. The already mentioned specimen from Kána represents an example for the latter (Fig. 8, bottom). ${ }^{36}$

Contrary, the raw material of the decorated needle holder found in Grave 1 at the $13^{\text {th }}-14^{\text {th }}$ century cemetery of Perkáta-Kőhalmi-dülő was identified as a crane ulna. ${ }^{37} \mathrm{~A}$ number of sharply cut and polished diaphysis sections, most possibly originating from goose long bones, were also found in the $12^{\text {th }}$ century workshop debitage of the site Orosháza $10 .{ }^{38}$ They do not bear any hole, similarly to the specimens found in the Iasian cemetery Négyszállási I. ${ }^{39}$

Needle boxes are thought to had been fixed on nomad bags according to their ethnographic counterparts. ${ }^{40}$ If holes were drilled on the bone case, they were closely placed next to each other for threading through the lace as the specimens from Debrecen and Kána prove. When bone tubes with similar shapes were carved for whistles, either a single air opening was made or the two openings were placed one after another as the flutes found in the medieval Royal Palace at Buda indicate. ${ }^{41}$
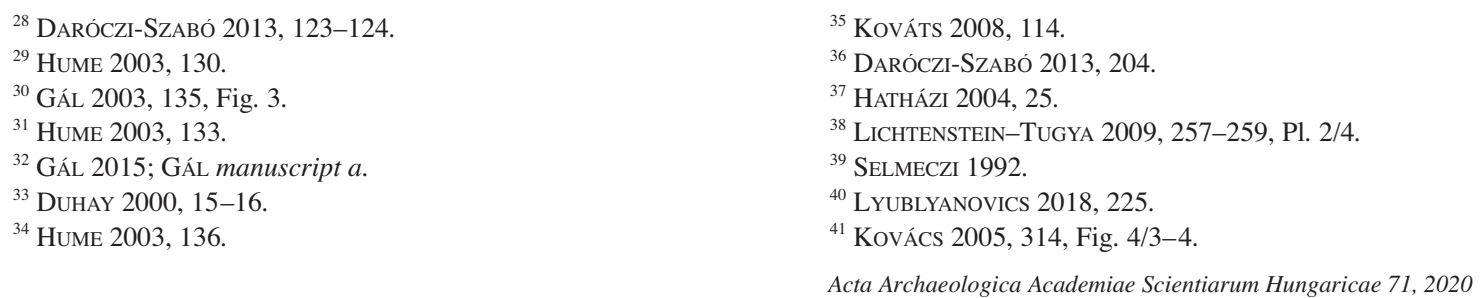


\section{CONCLUSIONS}

In spite of the relatively small bird bone assemblages found at Debrecen-Monostor-erdő and DebrecenTócó-part, a number of domestic and wild species providing food and other goods could be identified. The presence of two types of domestic chicken based on bone size distribution is first proved from rural settlements. According to the abundant goose assemblage including complete skeletons as well as the presence of healed bones evidencing human care, the remains from this species are rather assigned to the domestic than to the wild form, which, however. occasionally may have been also hunted, similarly to the duck species. The use of goose bones as raw material for producing objects is proved by two needle cases.

In addition to ordinary game birds hunted in the aquatic and steppe environment, various diurnal birds of prey occurring in marshlands and grasslands with scattered trees were also killed during the breeding and migration, and cold season. Their role in the life of settlers could not be totally clarified at this point. Some of them were most possibly persecuted, but others may have been exploited for their meat, wings and feathers just like in the case of crows whose consumption is proven by ethnographic data from the $20^{\text {th }}$ century. ${ }^{42}$ The symbolic role of certain species cannot be excluded, similarly to the use of trained saker falcon for hunting. Nevertheless, only the complete analysis of archaeological materials may bring light to these special aspects of human-bird interaction in the villages under study.

\section{ACKNOWLEDGEMENTS}

We are grateful to archaeologists Barbara Kolozsi, Zsigmond Hajdú, Emese Gyöngyvér Nagy, and László Szabó for inviting us to identify the animal bone assemblage from the sites of Debrecen-Monostor-erdő and Debrecen-Tócó-part, respectively. Mihály Gasparik is greatly acknowledged for providing access to the recent comparative bird bone collection housed in the Department of Geology and Palaeontology, Hungarian Natural History Museum.

Table 2. Measurements (mm) of avian bones according to the standard published by Angela von den Driesch. ${ }^{42}$ Abbreviations: GL $=$ greatest length; $\mathrm{Bp}=$ proximal breadth; $\mathrm{Dp}=$ proximal depth; $\mathrm{SD}=$ smallest diameter of the bone shaft $\mathrm{Bd}=$ distal breadth; $\mathrm{Dd}=$ distal dept $\mathrm{F}=\mathrm{female} ; \mathrm{M}=$ male; D-M = Debrecen-Monostor-erdő; D-T = Debrecen-Tócó-part; LM = Late Medieval; LM/EMP = Late Medieval/Early Modern Period

\begin{tabular}{|c|c|c|c|c|c|c|c|c|c|c|c|c|c|}
\hline Bone & Side & Note & GL & Bp & Dd & SD & Bd & Dd & Site & Feature & STR & $\begin{array}{l}\text { Type of } \\
\text { feature }\end{array}$ & Age \\
\hline \multicolumn{14}{|c|}{ Greylag goose/Domestic goose (Anser anser/A. domesticus) } \\
\hline coracoideum & $\sin$ & & 67.3 & & & & & & D-T & 310 & 755 & Well & $13^{\text {th }}-14^{\text {th }} c$. \\
\hline coracoideum & $\operatorname{dex}$ & & 70.4 & & & & & & D-M & 122 & 180 & Well & $10^{\text {th }}-13^{\text {th }} \mathrm{c}$. \\
\hline scapula & & & 94.7 & & & & & & D-M & 332 & 534 & Pit & $10^{\text {th }}-13^{\text {th }} \mathrm{c}$. \\
\hline humerus & $\sin$ & & 156.0 & 36.3 & & 11.1 & 23.7 & 13.1 & D-M & 120 & 178 & Well & $10^{\text {th }}-13^{\text {th }} \mathrm{c}$. \\
\hline humerus & dex & & 157.8 & 34.2 & & 10.9 & & & D-M & 143 & 212 & Well & $10^{\text {th }}-13^{\text {th }} \mathrm{c}$ \\
\hline humerus & dex & & & 30.6 & & 10.1 & & & D-T & 310 & 755 & Well & $13^{\text {th }}-14^{\text {th }} \mathrm{c}$. \\
\hline humerus & dex & & & 33.1 & & & & & D-T & 462 & 931 & Pit & $13^{\text {th }}-14^{\text {th }} c$. \\
\hline humerus & $\sin$ & & & 34.1 & & & & & D-T & 310 & 755 & Well & $13^{\text {th }}-14^{\text {th }} \mathrm{c}$. \\
\hline humerus & $\sin$ & & & 34.6 & & 10.8 & & & D-M & 120 & 178 & Well & $10^{\text {th }}-13^{\text {th }} c$. \\
\hline humerus & $\sin$ & & & & & & 24.6 & 14.2 & D-T & 462 & 931 & Pit & $13^{\text {th }}-14^{\text {th }} c$. \\
\hline ulna & dex & & 138.1 & 14.5 & 16.5 & 7.0 & 14.3 & 10.3 & D-T & 310 & 755 & Well & $13^{\text {th }}-14^{\text {th }} \mathrm{c}$. \\
\hline ulna & $\sin$ & & 139.8 & 14.6 & 15.5 & 7.0 & 14.4 & 9.9 & D-T & 310 & 755 & Well & $13^{\text {th }}-14^{\text {th }} \mathrm{c}$. \\
\hline ulna & $\operatorname{dex}$ & & & & & 7.8 & & 10.7 & D-M & 143 & 212 & Well & $10^{\text {th }}-13^{\text {th }} \mathrm{h} \mathrm{c}$. \\
\hline
\end{tabular}


Table 2. continued

\begin{tabular}{|c|c|c|c|c|c|c|c|c|c|c|c|c|c|}
\hline Bone & Side & Note & GL & Bp & Dd & SD & Bd & Dd & Site & Feature & STR & $\begin{array}{l}\text { Type of } \\
\text { feature }\end{array}$ & Age \\
\hline ulna & $\sin$ & & & & & & 15.5 & 10.8 & $\mathrm{D}-\mathrm{T}$ & 953 & 984 & Pit & Late Medieval \\
\hline ulna & $\sin$ & & & & & & 15.5 & 10.3 & D-T & 1373 & 1707 & Pit & Medieval \\
\hline radius & $\operatorname{dex}$ & & 131.6 & 8.2 & 7.8 & 4.9 & 9.8 & 5.0 & D-T & 310 & 755 & Well & $13^{\text {th }}-14^{\text {th }} \mathrm{c}$. \\
\hline radius & $\sin$ & & 132.0 & 8.3 & 7.3 & 4.8 & 9.8 & 5.1 & $\mathrm{D}-\mathrm{T}$ & 310 & 755 & Well & $13^{\text {th }}-14^{\text {th }} \mathrm{c}$. \\
\hline radius & $\operatorname{dex}$ & & 136.0 & 8.9 & 7.6 & 5.6 & 10.1 & 5.6 & D-M & 120 & 178 & Well & $10^{\text {th }}-13^{\text {th }} \mathrm{c}$. \\
\hline radius & $\operatorname{dex}$ & & 140.3 & 7.8 & & 5.9 & 10.6 & 5.2 & D-M & 143 & 212 & Well & $10^{\text {th }}-13^{\text {th }} \mathrm{c}$. \\
\hline radius & $\operatorname{dex}$ & & 143.2 & 8.2 & 9.1 & 4.8 & 9.8 & 5.6 & D-M & 213 & 324 & Pit & $10^{\text {th }}-13^{\text {th }} \mathrm{c}$. \\
\hline radius & & & & 7.4 & 8.0 & 5.4 & & & D-T & 1407 & 1756 & Pit & LM/EMP \\
\hline radius & $\sin$ & & & & & 4.5 & 10.6 & 5.5 & $\mathrm{D}-\mathrm{T}$ & 462 & 931 & Pit & LM/EMP \\
\hline carpometacarpus & $\sin$ & & 80.4 & & & & & & D-T & 310 & 755 & Well & $13^{\text {th }}-14^{\text {th }} c$. \\
\hline carpometacarpus & $\operatorname{dex}$ & & 80.6 & & & & & & D-T & 310 & 755 & Well & $13^{\text {th }}-14^{\text {th }} \mathrm{c}$ \\
\hline carpometacarpus & $\operatorname{dex}$ & & 83.4 & & & & & & D-M & 120 & 178 & Well & $10^{\text {th }}-13^{\text {th }} \mathrm{c}$. \\
\hline carpometacarpus & $\sin$ & & 83.5 & & & & & & D-M & 120 & 178 & Well & $10^{\text {th }}-13^{\text {th }} \mathrm{c}$. \\
\hline carpometacarpus & $\operatorname{dex}$ & & 86.6 & & & & & & D-M & 143 & 212 & Well & $10^{\text {th }}-13^{\text {th }} \mathrm{c}$. \\
\hline carpometacarpus & $\operatorname{dex}$ & & 88.3 & & & & & & D-M & 10 & 10 & House & $10^{\text {th }}-13^{\text {th }} \mathrm{c}$ \\
\hline femur & $\operatorname{dex}$ & & 70.8 & 19.9 & 13.8 & 7.3 & 18.4 & 15.0 & D-T & 310 & 755 & Well & $13^{\text {th }}-14^{\text {th }} \mathrm{c}$. \\
\hline femur & $\sin$ & & 70.8 & 19.9 & & 7.5 & 18.5 & 15.0 & D-T & 310 & 755 & Well & $13^{\text {th }}-14^{\text {th }} c$. \\
\hline femur & $\sin$ & & 76.3 & 20.1 & 13.5 & 7.9 & 19.6 & 15.7 & D-M & 120 & 178 & Well & $10^{\text {th }}-13^{\text {th }} c$. \\
\hline femur & $\operatorname{dex}$ & & 77.9 & 21.0 & 14.3 & 8.3 & 20.3 & 16.4 & D-T & 462 & 931 & Pit & LM/EMP \\
\hline tibiotarsus & dex & & 135.7 & 19.3 & 26.7 & 7.6 & 16.2 & 16.4 & D-M & 120 & 178 & Well & $10^{\text {th }}-13^{\text {th }} \mathrm{c}$. \\
\hline tibiotarsus & $\sin$ & & & 17.4 & 27.1 & & & & D-T & 310 & 755 & Well & $13^{\text {th }}-14^{\text {th }} \mathrm{c}$. \\
\hline tibiotarsus & $\sin$ & & & 17.9 & 8.1 & 6.6 & & & D-M & 120 & 178 & Well & $10^{\text {th }}-13^{\text {th }} \mathrm{c}$. \\
\hline tibiotarsus & dex & & & & & 7.6 & 15.6 & 16.0 & D-T & 557 & 1072 & Well & LM/EMP \\
\hline tarsometatarsus & $\sin$ & & 74.8 & 16.7 & & 7.3 & 17.7 & & D-T & 955 & 996 & Pit & LM/EMP \\
\hline tarsometatarsus & $\sin$ & & 78.9 & 17.4 & & 7.7 & 18.0 & & D-M & 120 & 178 & Well & $10^{\text {th }}-13^{\text {th }} \mathrm{c}$. \\
\hline tarsometatarsus & $\sin$ & & 85.8 & 18.6 & & 8.4 & 20.3 & & D-M & 97 & 149 & Well & $10^{\text {th }}-13^{\text {th }} \mathrm{c}$. \\
\hline \multicolumn{14}{|c|}{ Mallard/Domestic duck (Anas platyrhynchos/A. domestica) } \\
\hline coracoideum & $\sin$ & & 54.9 & & & & & & D-T & 726 & 1313 & Pit & Medieval \\
\hline ulna & $\sin$ & & 77.2 & 9.1 & 8.9 & 5.2 & 6.2 & 9.4 & D-M & 212 & 322 & House & $10^{\text {th }}-13^{\text {th }} \mathrm{c}$. \\
\hline radius & $\sin$ & & 72.8 & & & & & & D-M & 212 & 322 & House & $10^{\text {th }}-13^{\text {th }} c$. \\
\hline radius & $\sin$ & & & & & & 7.0 & 3.8 & D-T & 726 & 1313 & Pit & Medieval \\
\hline carpometacarpus & $\sin$ & & 52.6 & & & & & & D-T & 726 & 1313 & Pit & Medieval \\
\hline femur & $\sin$ & & & & & 5.3 & 12.0 & 9.8 & D-T & 726 & 1313 & Pit & Medieval \\
\hline \multicolumn{14}{|c|}{ Northern shoveler (Anas clypeata) } \\
\hline humerus & $\operatorname{dex}$ & & 74.1 & 16.3 & & 5.4 & 11.2 & 7.5 & D-M & 361 & 592 & House & $10^{\text {th }}-13^{\text {th }} \mathrm{c}$. \\
\hline \multicolumn{14}{|c|}{ Red kite (Milvus milvus) } \\
\hline tarsometatarsus & $\operatorname{dex}$ & & 54.9 & & & 6.0 & 14.8 & & D-M & 465 & 801 & & $10^{\text {th }}-13^{\text {th }} \mathrm{c}$. \\
\hline \multicolumn{14}{|c|}{ Buzzard (Buteo buteo) } \\
\hline ulna & $\operatorname{dex}$ & & 129.7 & 13.2 & 14.0 & 6.2 & 10.6 & 5.5 & $\mathrm{D}-\mathrm{T}$ & 462 & 931 & Pit & LM/EMP \\
\hline radius & $\operatorname{dex}$ & & 122.3 & 6.5 & 4.5 & 2.9 & 8.5 & & D-T & 462 & 931 & Pit & LM/EMP \\
\hline carpometacarpus & $\operatorname{dex}$ & & 65.7 & 15.2 & & & 10.1 & 7.5 & D-T & 462 & 931 & Pit & LM/EMP \\
\hline \multicolumn{14}{|c|}{ Partridge (Perdix perdix) } \\
\hline humerus & $\operatorname{dex}$ & & 51.0 & 13.4 & & 4.3 & 10.0 & 5.3 & D-T & 467 & 946 & Pit & Medieval \\
\hline \multicolumn{14}{|c|}{ Domestic chicken (Gallus domesticus) } \\
\hline coracoideum & $\operatorname{dex}$ & & 49.5 & & & & & & D-T & 327 & 770 & Well & Medieval \\
\hline coracoideum & $\sin$ & & 49.9 & & & & & & D-T & 327 & 770 & Well & Medieval \\
\hline coracoideum & $\sin$ & & 50.5 & & & & & & D-T & 436 & 915 & Well & LM/EMP \\
\hline coracoideum & $\operatorname{dex}$ & & 50.6 & & & & & & D-T & 436 & 915 & Well & LM/EMP \\
\hline humerus & $\operatorname{dex}$ & & 56.9 & & & 6.0 & 12.3 & 6.8 & D-M & 271 & 412 & & $14^{\text {th }} \mathrm{c}$ \\
\hline
\end{tabular}


Table 2. continued

\begin{tabular}{|c|c|c|c|c|c|c|c|c|c|c|c|c|c|}
\hline Bone & Side & Note & GL & Bp & Dd & SD & Bd & Dd & Site & Feature & STR & $\begin{array}{l}\text { Type of } \\
\text { feature }\end{array}$ & Age \\
\hline humerus & $\sin$ & $\mathrm{F}$ & 57.3 & 15.7 & & 6.0 & 12.3 & 6.9 & D-M & 271 & 412 & & $14^{\text {th }} \mathrm{c}$ \\
\hline humerus & $\operatorname{dex}$ & & 57.5 & & & 5.1 & & & D-M & 293 & 459 & & $14^{\text {th }} \mathrm{c}$. \\
\hline humerus & $\sin$ & & 61.4 & 16.6 & & 5.5 & 13.3 & 6.7 & D-T & 953 & 984 & Pit & Late Medieval \\
\hline humerus & $\operatorname{dex}$ & & 62.0 & 18.4 & & 6.1 & 13.6 & 7.3 & D-T & 327 & 770 & Well & Medieval \\
\hline humerus & $\sin$ & & 62.1 & 17.0 & & 6.2 & 14.0 & 7.4 & D-M & 412 & 690 & Pit & $10^{\text {th }}-13^{\text {th }} c$. \\
\hline humerus & $\operatorname{dex}$ & & 62.3 & 17.5 & & 6.8 & 13.9 & 7.6 & D-M & 188 & 342 & Pit & $10^{\text {th }}-13^{\text {th }} c$. \\
\hline humerus & $\operatorname{dex}$ & $\mathrm{F}$ & 63.2 & 17.2 & & 6.4 & 13.6 & 7.4 & D-M & 337 & 539 & Pit & $10^{\text {th }}-13^{\text {th }} \mathrm{c}$. \\
\hline humerus & $\sin$ & $\mathrm{F}$ & 63.5 & 17.6 & & 6.4 & 13.6 & 7.5 & D-M & 337 & 539 & Pit & $10^{\text {th }}-13^{\text {th }} \mathrm{c}$. \\
\hline humerus & $\operatorname{dex}$ & & 71.1 & 19.9 & & 7.5 & 15.3 & 8.6 & D-T & 313 & 758 & Pit & Medieval \\
\hline humerus & $\sin$ & & 71.2 & 20.1 & & 6.9 & 15.8 & 8.7 & D-T & 313 & 758 & Pit & Medieval \\
\hline humerus & $\operatorname{dex}$ & & 72.0 & 19.1 & & 7.1 & 15.3 & 8.3 & D-M & 366 & 599 & House & $10^{\text {th }}-13^{\text {th }} \mathrm{c}$. \\
\hline humerus & $\operatorname{dex}$ & & & 16.9 & & & & & D-M & 10 & 10 & House & $10^{\text {th }}-13^{\text {th }} \mathrm{c}$. \\
\hline humerus & $\sin$ & & & 17.5 & & 5.9 & & & D-T & 984 & 1604 & Pit & Medieval \\
\hline humerus & dex & & & 17.7 & & 6.2 & & & D-T & 436 & 915 & Well & LM/EMP \\
\hline humerus & $\sin$ & & & 17.9 & & 6.2 & & & D-T & 436 & 915 & Well & LM/EMP \\
\hline humerus & $\operatorname{dex}$ & & & 18.3 & & & & & D-T & 856 & 1469 & Pit & $13^{\text {th }}-14^{\text {th }} \mathrm{c}$. \\
\hline humerus & $\operatorname{dex}$ & & & & & 6.3 & 13.5 & 7.3 & D-M & 133 & 202 & Pit & $10^{\text {th }}-13^{\text {th }} \mathrm{c}$. \\
\hline humerus & $\sin$ & & & & & 6.9 & 15.0 & 8.4 & D-M & 361 & 592 & House & $10^{\text {th }}-13^{\text {th }} \mathrm{c}$. \\
\hline ulna & $\operatorname{dex}$ & & 59.4 & 7.7 & 11.4 & 3.6 & 8.9 & 6.6 & D-T & 327 & 770 & Well & Medieval \\
\hline ulna & $\operatorname{dex}$ & $\mathrm{F}$ & 60.3 & 7.9 & 11.1 & 3.8 & 8.7 & 6.6 & D-M & 337 & 539 & Pit & $10^{\text {th }}-13^{\text {th }} \mathrm{c}$. \\
\hline ulna & $\operatorname{dex}$ & & 65.8 & 8.7 & 12.1 & 3.8 & 9.4 & 6.8 & D-M & 412 & 690 & Pit & $10^{\text {th }}-13^{\text {th }} \mathrm{c}$. \\
\hline ulna & $\sin$ & & 69.5 & 8.9 & 12.8 & 4.1 & 10.3 & 7.0 & D-T & 313 & 758 & Pit & Medieval \\
\hline ulna & dex & & 69.7 & 8.9 & 12.8 & 4.3 & 10.2 & 7.1 & D-T & 313 & 758 & Pit & Medieval \\
\hline ulna & $\operatorname{dex}$ & & 71.1 & 9.3 & 12.3 & 4.2 & 10.1 & 6.7 & D-T & 462 & 931 & Pit & LM/EMP \\
\hline ulna & $\sin$ & & & 7.8 & 11.7 & & 8.7 & 6.5 & D-T & 436 & 915 & Well & LM/EMP \\
\hline ulna & $\operatorname{dex}$ & & & 8.2 & 11.5 & & & & D-T & 436 & 915 & Well & LM/EMP \\
\hline ulna & $\operatorname{dex}$ & & & 8.3 & & 4.0 & 9.2 & 6.3 & D-T & 403 & 882 & Pit hole & $13^{\text {th }}-14^{\text {th }} \mathrm{c}$. \\
\hline ulna & $\sin$ & & & 8.9 & & 4.1 & 10.0 & 6.9 & D-T & 959 & 1000 & Well & LM/EMP \\
\hline ulna & $\sin$ & & & & & & 8.9 & 6.5 & D-M & 337 & 539 & Pit & $10^{\text {th }}-13^{\text {th }} \mathrm{c}$. \\
\hline radius & $\sin$ & & 54.0 & 4.8 & 5.1 & 2.9 & 6.1 & 3.7 & D-T & 327 & 770 & Well & Medieval \\
\hline radius & $\sin$ & & 56.4 & 4.2 & 5.0 & 3.0 & 6.0 & 3.2 & D-T & 773 & 1365 & Pit & $10^{\text {th }}-13^{\text {th }} \mathrm{c}$. \\
\hline radius & $\sin$ & & 62.4 & 5.0 & 5.6 & 3.3 & 6.9 & 3.8 & D-T & 313 & 758 & Pit & Medieval \\
\hline radius & $\operatorname{dex}$ & & 62.9 & 5.3 & 5.6 & 3.2 & 7.0 & 3.9 & D-T & 313 & 758 & Pit & Medieval \\
\hline radius & $\operatorname{dex}$ & & 64.4 & 5.4 & 5.6 & 3.1 & 6.9 & 4.4 & D-T & 984 & 1604 & Pit & Medieval \\
\hline radius & $\operatorname{dex}$ & & 68.9 & 6.1 & 6.2 & 3.6 & 7.8 & 4.1 & D-T & 954 & 995 & Pit & $10^{\text {th }}-13^{\text {th }} c$. \\
\hline radius & $\sin$ & & & 4.7 & 4.8 & 2.7 & & & D-T & 856 & 1469 & Pit & $13^{\text {th }}-14^{\text {th }} \mathrm{c}$. \\
\hline radius & $\operatorname{dex}$ & & & 5.3 & 5.7 & 3.1 & & & D-T & 856 & 1469 & Pit & $13^{\text {th }}-14^{\text {th }} \mathrm{c}$. \\
\hline carpometacarpus & $\sin$ & & 38.5 & & & & & & D-T & 313 & 758 & Pit & Medieval \\
\hline carpometacarpus & $\operatorname{dex}$ & & 38.6 & & & & & & D-T & 313 & 758 & Pit & Medieval \\
\hline carpometacarpus & $\sin$ & & 40.6 & & & & & & D-T & 462 & 931 & Pit & LM/EMP \\
\hline femur & $\sin$ & & 67.0 & 14.3 & 9.6 & 6.5 & 13.2 & 10.8 & D-M & 412 & 690 & Pit & $10^{\text {th }}-13^{\text {th }} \mathrm{c}$. \\
\hline femur & $\operatorname{dex}$ & $\mathrm{F}$ & 68.8 & 13.9 & 9.2 & 6.1 & 13.4 & 10.8 & D-M & 337 & 539 & Pit & $10^{\text {th }}-13^{\text {th }} \mathrm{c}$. \\
\hline femur & $\sin$ & & 68.9 & 15.3 & 10.1 & 5.9 & 14.0 & 12.0 & D-T & 327 & 770 & Well & Medieval \\
\hline femur & $\sin$ & $\mathrm{F}$ & 69.1 & 14.4 & 9.6 & 6.2 & 13.4 & 11.4 & D-M & 337 & 539 & Pit & $10^{\text {th }}-13^{\text {th }} c$. \\
\hline femur & $\sin$ & & 71.6 & 15.3 & 10.3 & 6.1 & & & D-T & 462 & 931 & Pit & LM/EMP \\
\hline femur & $\sin$ & & 72.1 & 15.5 & 10.4 & 6.8 & 14.8 & 12.0 & D-T & 689 & 1259 & Pit & $10^{\text {th }}-13^{\text {th }} \mathrm{c}$. \\
\hline femur & $\sin$ & & 72.5 & 15.2 & 10.0 & 6.2 & 14.0 & 11.9 & D-T & 436 & 915 & Well & LM/EMP \\
\hline femur & $\operatorname{dex}$ & & 73.2 & & & 5.8 & 14.1 & 11.7 & D-T & 436 & 915 & Well & LM/EMP \\
\hline
\end{tabular}


Table 2. continued

\begin{tabular}{|c|c|c|c|c|c|c|c|c|c|c|c|c|c|}
\hline Bone & Side & Note & GL & Bp & Dd & SD & Bd & Dd & Site & Feature & STR & $\begin{array}{l}\text { Type of } \\
\text { feature }\end{array}$ & Age \\
\hline femur & $\sin$ & & 74.9 & 14.6 & 14.3 & 11.7 & 15.8 & 12.9 & D-M & 214 & 326 & Pit & $10^{\text {th }}-13^{\text {th }} \mathrm{c}$. \\
\hline femur & dex & & 79.3 & 16.8 & 11.0 & 6.8 & 16.1 & 12.9 & D-T & 313 & 758 & Pit & Medieval \\
\hline femur & $\sin$ & & 79.5 & 16.5 & 10.7 & 6.9 & 15.7 & 13.4 & D-T & 313 & 758 & Pit & Medieval \\
\hline femur & dex & & & 14.1 & 9.3 & & & & D-M & 412 & 690 & Pit & $10^{\text {th }}-13^{\text {th }} c$. \\
\hline femur & $\sin$ & & & 14.2 & 9.4 & 5.4 & & & D-M & 271 & 412 & & $14^{\text {th }} \mathrm{c}$. \\
\hline femur & dex & & & 17.3 & 11.7 & & & & D-M & 346 & 555 & House & $10^{\text {th }}-13^{\text {th }} \mathrm{c}$. \\
\hline femur & $\sin$ & & & 14.4 & 9.2 & 5.5 & 13.3 & 10.9 & D-M & 337 & 539 & Well & $10^{\text {th }}-13^{\text {th }} \mathrm{c}$. \\
\hline femur & dex & $\mathrm{F}$ & & & & 6.0 & 13.6 & & D-M & 101 & 153 & Pit & $10^{\text {th }}-13^{\text {th }} c$. \\
\hline femur & dex & & & & & 5.5 & 12.1 & 10.1 & D-M & 271 & 412 & & 14th c. \\
\hline tibiotarsus & $\sin$ & & 92.0 & 14.9 & 16.0 & 5.6 & 10.1 & 10.6 & D-M & 412 & 690 & Pit & $10^{\text {th }}-13^{\text {th }} \mathrm{c}$. \\
\hline tibiotarsus & dex & & 92.7 & 14.8 & 15.5 & 5.4 & 9.9 & 10.6 & D-M & 412 & 690 & Pit & $10^{\text {th }}-13^{\text {th }} c$ \\
\hline tibiotarsus & dex & & 95.1 & 15.9 & 18.9 & 5.2 & 10.5 & 11.1 & D-T & 327 & 770 & Well & Medieval \\
\hline tibiotarsus & $\sin$ & $\mathrm{F}$ & 95.8 & 15.7 & 17.3 & 4.9 & 10.0 & 10.4 & D-M & 337 & 539 & Pit & $10^{\text {th }}-13^{\text {th }} c$. \\
\hline tibiotarsus & dex & $\mathrm{F}$ & 96.8 & 14.3 & 17.0 & 5.4 & 10.1 & 11.1 & D-M & 337 & 539 & Pit & $10^{\text {th }}-13^{\text {th }} \mathrm{c}$. \\
\hline tibiotarsus & dex & & 106.4 & & & 6.0 & 10.8 & 11.7 & D-M & 412 & 690 & Pit & $10^{\text {th }}-13^{\text {th }} \mathrm{c}$. \\
\hline tibiotarsus & $\operatorname{dex}$ & & 107.1 & 17.3 & 20.2 & 6.3 & 11.2 & 11.6 & D-M & 268 & 409 & & 14th c. \\
\hline tibiotarsus & $\sin$ & & 111.1 & 19.0 & 20.5 & 6.5 & 12.3 & 12.4 & D-T & 313 & 758 & Pit & Medieval \\
\hline tibiotarsus & $\operatorname{dex}$ & & 111.5 & 17.7 & 20.3 & 6.5 & 12.5 & 12.3 & D-T & 313 & 758 & Pit & Medieval \\
\hline tibiotarsus & $\sin$ & & 114.6 & 17.6 & & 6.3 & 11.5 & 12.8 & D-M & 362 & 594 & Well & $10^{\text {th }}-13^{\text {th }} \mathrm{c}$. \\
\hline tibiotarsus & $\sin$ & & & 14.7 & 16.9 & & & & D-M & 337 & 539 & Pit & $10^{\text {th }}-13^{\text {th }} c$. \\
\hline tibiotarsus & dex & $\mathrm{F}$ & & 16.1 & & & & & D-T & 436 & 915 & Well & LM/EMP \\
\hline tibiotarsus & $\sin$ & & & 17.5 & & 6.2 & & & D-M & 362 & 594 & Well & $10^{\text {th }}-13^{\text {th }} c$. \\
\hline tibiotarsus & $\sin$ & & & & & 5.3 & 10.0 & 10.5 & D-M & 392 & 650 & Well & $10^{\text {th }}-13^{\text {th }} \mathrm{c}$. \\
\hline tibiotarsus & dex & & & & & 5.3 & 10.6 & 10.4 & D-T & 953 & 984 & Pit & Late Medieval \\
\hline tibiotarsus & $\operatorname{dex}$ & & & & & 5.8 & 11.6 & 12.1 & D-T & \begin{tabular}{|l|}
507 \\
\end{tabular} & 1007 & Pit & $13^{\text {th }}-14^{\text {th }} \mathrm{c}$ \\
\hline tarsometatarsus & $\sin$ & & 62.7 & 11.4 & & 5.8 & 11.1 & & D-M & 412 & 690 & Pit & $10^{\text {th }}-13^{\text {th }} \mathrm{c}$. \\
\hline tarsometatarsus & $\sin$ & & 64.0 & 12.3 & & 5.6 & 11.9 & & D-T & 327 & 770 & Well & Medieval \\
\hline tarsometatarsus & $\sin$ & $\mathrm{M}$ & 66.2 & 11.5 & & 5.8 & 12.0 & & D-T & 476 & 955 & Well & Medieval \\
\hline tarsometatarsus & dex & $\mathrm{F}$ & 66.4 & 11.5 & & 5.3 & 11.8 & & D-M & 337 & 539 & Pit & $10^{\text {th }}-13^{\text {th }} \mathrm{c}$. \\
\hline tarsometatarsus & $\sin$ & $\mathrm{F}$ & 68.2 & 12.3 & & 6.0 & 12.0 & & D-T & 462 & 931 & Pit & LM/EMP \\
\hline tarsometatarsus & $\sin$ & $\mathrm{F}$ & 71.0 & 12.5 & & 5.5 & 12.7 & & D-T & 436 & 915 & Well & LM/EMP \\
\hline tarsometatarsus & $\operatorname{dex}$ & $\mathrm{F}$ & 71.5 & 12.1 & & 5.5 & 12.4 & & D-T & 436 & 915 & Well & LM/EMP \\
\hline tarsometatarsus & $\operatorname{dex}$ & M & 76.3 & 13.6 & & 6.3 & 13.0 & & D-M & 268 & 409 & 861 & $14^{\text {th }} \mathrm{c}$. \\
\hline tarsometatarsus & $\sin$ & & 77.5 & 14.3 & & 6.6 & 13.9 & & D-T & 313 & 758 & Pit & Medieval \\
\hline tarsometatarsus & dex & M & 78.6 & 13.6 & & 6.6 & 13.3 & & D-T & 462 & 931 & Pit & LM/EMP \\
\hline tarsometatarsus & $\sin$ & M & 78.6 & 14.4 & & 7.6 & 11.5 & & D-T & 1393 & 1741 & Well & Medieval \\
\hline tarsometatarsus & $\operatorname{dex}$ & $\mathrm{F}$ & & & & 5.6 & 12.2 & & D-T & 530 & 1030 & Pit & Medieval \\
\hline \multicolumn{14}{|c|}{ Northern lapwing (Vanellus vanellus) } \\
\hline humerus & $\sin$ & & 60.3 & 13.7 & & 4.1 & 10.2 & 6.0 & D-T & 358 & 837 & Pit & $13^{\text {th }}-14^{\text {th }} c$. \\
\hline \multicolumn{14}{|c|}{ Rook/Hooded crow (Corvus frugilegus/C. corone) } \\
\hline humerus & dex & & 68.8 & & & 6.7 & 17.1 & 7.6 & D-M & 188 & 281 & House & $10^{\text {th }}-13^{\text {th }} \mathrm{c}$. \\
\hline ulna & $\sin$ & & & & & 4.4 & 9.3 & 6.7 & D-M & 188 & 281 & House & $10^{\text {th }}-13^{\text {th }} c$. \\
\hline femur & $\operatorname{dex}$ & & 48.8 & & & 4.3 & 10.2 & & D-M & 188 & 281 & House & $10^{\text {th }}-13^{\text {th }} \mathrm{c}$. \\
\hline tarsometatarsus & $\sin$ & & 62.2 & 10.3 & & 3.9 & 6.5 & & D-T & 952 & 993 & Pit & LM \\
\hline
\end{tabular}




\section{REFERENCES}

BARON 2018

BARTOSIEWICZ 2012

BARTOSIEWICZ-GÁL 2003

BARTOSIEWICZ-GÁL 2013

BARTOSIEWICZ et al. 2018

Collaert 1967

DARÓCZI-SZABÓ 2012

DARÓCZI-SZABÓ 2013

VON DEN DRIESCH

DUHAY 2000

GÁL 2003

GÁL 2005

GÁL 2008

GÁL 2015

GÁL 2020

GÁL manuscript a

GÁL manuscript $b$

HAJDÚ-NAGY

HAJDÚ-NAGY
$=$ H. BARON: From Arthrosis to Necrosis: Many, many pathological chickens from the Avar cemetery at Vienna Csokorgasse, Austria. In: Care or Neglect? Evidence of Animal Disease in Archaeology. Proceedings of the Animal Palaeopathology Working Group of the International Council for Archaeozoology (ICAZ), Budapest, Hungary, 2016. Eds: L. Bartosiewicz, E. Gál. Oxford-Philadelphia 2018, 208-229.

= L. BARTosiewicz: Show me your hawk, I'll tell you who you are. In: A Bouquet of Archaeozoological Studies. Essays in honour of Wietske Prummel. Eds: D. C. M. Raemaekers, K. Esser, R. C. G. M. Lauwerier, J. T. Zeiler. Groningen 2012, 178-187.

= L. BARTOSIEWICZ -E. GÁL: Animal exploitation in Hungary during the Ottoman Era. In: Archaeology of the Ottoman Period in Hungary. Papers of the conference held at the Hungarian National Museum, Budapest, 24-26 May 2000. Eds: I. Gerelyes, Gy. Kovács. Budapest 2003, 365-376.

= L. BArtosiewicZ-E. GÁL: Shuffling Nags, Lame Ducks. The Archaeology of Animal Disease. Oxford 2013.

= L. BartosiewicZ-A. Zs. Biller-P. Csippán-L. DarócZi-Szabó-M. DarócZi-Szabó-E. GálI. Kováts-K. Lyublyanovics- É. Á. Nyerges: Animal exploitation in medieval Hungary. In: The Economy of Medieval Hungary. Eds: J. Laszlovszky, B. Nagy, P. Szabó, A. Vadas. Leiden-Boston 2018, 113-165.

= A. Collaert: Avium vivae icones. Culture et civilization. Bruxelles 1967.

= M. DARÓCZI-SzABó: Debrecen-Tócó-part lelőhely archeozoológiai vizsgálata [Archaeozoological analysis of the site of Debrecen-Tócó-part]. Magyar Nemzeti Múzeum Régészeti Adatbázis [Archaeological Database of the Hungarian National Museum]. https://archeodatabase.hnm.hu/hu/ node/1771, visited on $29^{\text {th }}$ December 2019.

= M. DARÓCZI-SzABó: Az Árpád-kori Kána falu állatcsontjainak vizsgálata [Animal remains from the Árpád Period village of Kána, Hungary]. PhD thesis. Eötvös Loránd University, Faculty of Humanities. Budapest 2013.

= A. VON DEN DRIESCH: A Guide to the Measurements of Animal Bones from Archaeological Sites. Peabody Museum Bulletin 1. Cambridge, MA 1976.

$=\mathrm{G}$. DUHAY: Ragadozómadár-tartás és a solymászat természetvédelmi vonatkozásai [Raptor keeping and the nature conservation aspects of fowling]. In: Természetvédelmi ismeretek a madár- és denevérgyürüzési, valamint a solymászvizsgához [Knowledge of Nature Conservation for Bird and Bat Ringing and Fowling Exam]. Ed.: Zs. Kalotás. Budapest 2000, 83-113.

= E. GÁL: Adaptation of different bird species to human environments. In: People and Nature in Historical Perspective. Eds: J. Laszlovszky, P. Szabó. Budapest 2003, 120-138.

= E. GÁL: New data to the bird bone artefacts from Hungary and Romania. In: From Hooves to Horns, from Mollusc to Mammoth. Manufacture and Use of Bone Artefacts from Prehistoric Times to the Present. Proceedings of the 4th Meeting of the ICAZ Worked Bone Research Group at Tallinn. $26^{\text {th }}$ $31^{\text {st }}$ of August 2003. Eds: H. Luik, A. M. Choyke, C. E. Batey, L. Lõugas. Tallinn 2005, 325-338. = E. GÁL: A középkori madarászat régészeti állattani emlékei [Memories of the medieval fowling]. In: Gazdaság és gazdálkodás a középkori Magyarországon: gazdaságtörténet, anyagi kultúra, régészet [Economy and Agriculture in Medieval Hungary: Agricultural, material culture, archaeology]. Eds: A. Kubinyi, J. Laszlovszky, P. Szabó. Budapest 2008, 109-112.

= E. GÁL: "Fine feathers make fine birds": the exploitation of wild birds in medieval Hungary. Antaeus 33 (2015) 345-368.

= E. GÁL: Remains of small domestic and game birds from medieval sites in Hungary. Quaternary International 545 (2020) 99-107.

= E. GÁL: Házi- és vadászott állatok a középkori Kárpát-medencében [Domestic and hunted animals in the medieval Carpathian Basin]. In: A Kárpát-medence környezettörténete a középkorban és a kora újkorban [Environmental History of the Carpathian Basin during the Middle Ages and Early Modern Period]. Eds: E. Benkő, Cs. Zatykó. Budapest, in press.

= E. GÁL: Régészeti állattani eredmények az esztergomi érseki konyha szeméthalmának feltárása nyomán [Archaeozoological analysis of the archbishopric kitchen dump at Esztergom]. In: A Kárpát-medence környezettörténete a középkorban és a kora újkorban [Environmental History of the Carpathian Basin during the Middle Ages and Early Modern Period]. Eds: E. Benkő, Cs. Zatykó. Budapest, in press.

= Zs. HAJDÚ-E. Gy. NAGY: Debrecen, Tócó-part, Erdőalja. In: Régészeti kutatások Magyarországon 2008. Ed.: J. Kisfaludi. Budapest 2009, 180-181.

= Zs. HAJdú-E. Gy. NAGY: Debrecen, Tócó-part, Erdőalja. In: Régészeti kutatások Magyarországon 2009. Ed.: J. Kisfaludi. Budapest 2010, 182-183. 
HATHÁZI 2004

HuME 2003

LYUBLYANOVICS 2017

KARDOS 1943

KoLOZSI 2012a

KoLOZSI 2012b

KovÁCS 2005

KovÁts 2008

LiCHTENSTEIN-TUGYA 2009

Peterson et al. 1977

SELMECZI 1992

SERJEANTSON 2009

TOMEK - BOCHENSKI 2000

VÖRÖs 2003
= G. HATHÁZI: A kunok régészeti emlékei a kelet-dunántúlon [The Archaeological Heritage of Cumans in Eastern Transdanubia]. Budapest 2004.

= R. HumE: Madárvilág Európában [Birds in Europe]. Budapest 2003.

= K. LyUBLYANOvics: New Home, New Herds. Cuman integration and animal husbandry in medieval Hungary from an archaeozoological perspective. Oxford 2017.

= L. KARDOS: Az Őrség népi táplálkozása [Traditional Food in the Őrség Region]. Budapest 1943.

= B. KolozsI: Debrecen, Monostor-erdö (KÖH 36763) (Hajdú-Bihar megye). In: Régészeti kutatások Magyarországon 2010. Ed.: J. Kisfaludi. Budapest 2012, 211.

= B. KolozsI: Debrecen - Tócó-part régészeti lelőhely feldolgozása. Magyar Nemzeti Múzeum Régészeti Adatbázis. https://archeodatabase.hnm.hu/hu/node/1771, visited on $27^{\text {th }}$ November 2019.

$=$ E. Kovács: Remains of the bone working in medieval Buda. In: From Hooves to Horns, from Mollusc to Mammoth. Manufacture and Use of Bone Artefacts from Prehistoric Times to the Present. Proceedings of the 4th Meeting of the ICAZ Worked Bone Research Group at Tallinn, 26th-31st of August 2003. Eds: H. Luik, A. M. Choyke, C. Batey, L. Lõugas. Tallinn 2005, 309-316.

= I. KovÁts: A középkori csontmegmunkálás [The medieval bone working]. In: Gazdaság és gazdálkodás a középkori Magyarországon: gazdaságtörténet, anyagi kultúra, régészet [Economy and Agriculture in Medieval Hungary: Agricultural, material culture, archaeology]. Eds: A. Kubinyi, J. Laszlovszky, P. Szabó. Budapest 2008, 113-116.

= L. Lichtenstein-B. TugYA: Adatok a 12. század végi Orosháza iparához. Egy csontmegmunkáló mühely hulladékanyaga (Data on the late $12^{\text {th }}$ century bone industry of Orosháza. Bone manufacturing refuse from a workshop). In: Csontvázak a szekrényből (Skeletons from the Cupboard). Eds: L. Bartosiewicz, E. Gál, I. Kováts. Budapest 2009, 251-263.

$=$ R. T. Peterson-G. Mountfort-P. A. D. Hollom: Európa madarai [Birds of Europe]. Budapest 1977.

= T. Selmeczi: A négyszállási I. számú jász temető (Der Friedhof Nr. I. der Jaßen von Négyszállás). Budapest 1992.

= D. SERJEANTSOn: Birds. Cambridge 2009.

$=$ T. TOMEK - Z. M. Bochenski: A Key for the Identification of Domestic Bird Bones in Europe: Galliformes and Columbiformes. Institute of Systematics and Evolution of Animals, Polish Academy of Sciences, Kraków 2000.

= I. VöRÖs: Sixteenth- and seventeenth-century animal bone finds in Hungary. In: Archaeology of the Ottoman Period in Hungary. Eds: I. Gerelyes, Gy. Kovács. Budapest 2003, 351-364.

Open Access statement. This is an open-access article distributed under the terms of the Creative Commons Attribution-NonCommercial 4.0 International License (https://creativecommons.org/licenses/by-nc/4.0/), which permits unrestricted use, distribution, and reproduction in any medium for non-commercial purposes, provided the original author and source are credited, a link to the CC License is provided, and changes - if any - are indicated. 
